\section{Exploring the Patterns of Food Waste Generation by Tourists in a Popular Destination}

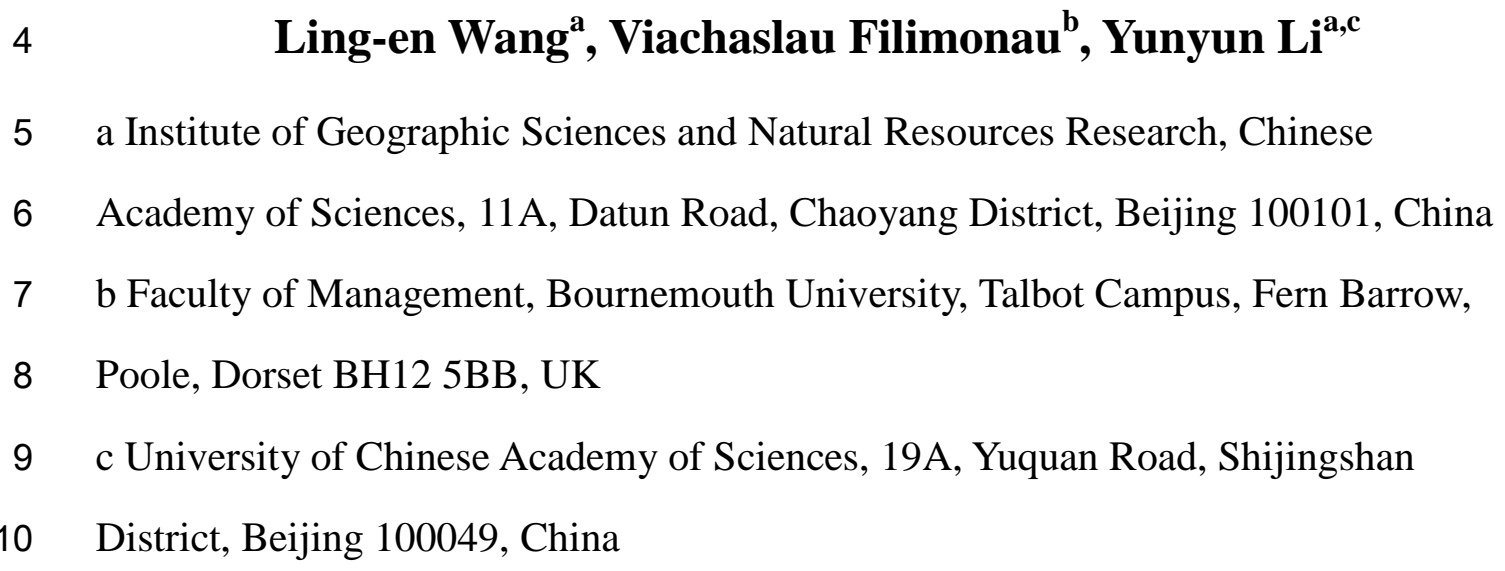

9 c University of Chinese Academy of Sciences, 19A, Yuquan Road, Shijingshan

corespongding author: Yunyun Li, email:liyy.17b@igsnrr.ac.cn

\section{Acknowledgments}

The authors very much appreciate student volunteers from Tibet University, all interviewed questionnaire respondents in our field survey. This work was supported by the National Youth Science Foundation under Grant number 41701620; Industrial Fusion Technology Demonstration Base for Rural Revitalization under Grant number SCKJ004; and the Second Tibetan Plateau Scientific Expedition and Research Program (STEP) under Grant number 2019QZKK1002.

Declarations of interest: none. 
Exploring the Patterns of Food Waste Generation by Tourists in a Popular

\section{Destination}

31

32

Abstract:

Tourist food consumption is an important driver of food waste generation within the hotel/restaurant/café (HORECA) sector of popular destinations. Little is however known about the exact magnitude of food wastage by tourists alongside the determinants of their wasteful behaviour. This study contributed to knowledge with an exploratory survey in Lhasa, a popular destination in China, which set to establish the size of food wastage by tourists and explain the role of various socio-demographic and food consumption-related factors in its occurrence. The study found that tourists generated circa $15 \%$ of the total food waste in the HORECA sector and taste preferences and portion size are two major causes. The level of tourist education and personal satisfaction with meals exert a significant negative impact on food waste generation. To reduce food wastage, policy-makers and HORECA professionals should educate tourists about the detrimental effect of wasted food and increase their satisfaction with meals.

\section{Keywords:}

food waste; tourism; consumption; mitigation; HORECA; China

\section{Introduction}

Food waste is a global societal challenge which has been recognised by various stakeholders (Aschemann-Witzel, de Hooge, Amani, Bech-Larsen, \& Oostindjer, 2015; Papargyropoulou, Lozano, Steinberger, Wright, \& bin Ujang, 2014; Parfitt, Barthel, \& Macnaughton, 2010). The global wastage of approximately one third of the food 
produced for human consumption not only imposes excessive pressures on natural resources, but also generates substantial carbon footprint (FAO, 2013). From the policy perspective, the challenge of food waste is costly: for example, in the USA, where up to $40 \%$ of food gets either lost or wasted, the disposal costs of this waste account for $1.3 \%$ of the country's GDP (ReFED, 2016). The challenge of food waste is particularly concerning given that more than 820 million people globally suffer from hunger (FAO, IFAD, UNICEF, WFP, \& WHO, 2018). Meaning that food wastage does not only imply lost and/or wasted natural and financial resources, but also represents an important moral and social equality issue (Dobson, 2015).

Food consumption constitutes an integral element of a holiday experience and it can therefore be assumed that tourism contributes to global food wastage (S. K. Cheng, Jin, Liu, Liu, \& Yu, 2018). This notwithstanding, the research agenda on tourism's food waste is under-developed (L. E. Wang, et al., 2018). Although a growing number of studies are examining the food waste challenge within the national hotel/restaurant/café (HORECA) sectors of popular tourist destinations (see, for example, (Filimonau, Fidan, Alexieva, Dragoev, \& Marinova, 2019; Kasavan, Mohamed, \& Halim, 2019; Papargyropoulou, et al., 2019), they do not differentiate between food wastage by tourists and local residents. This is primarily attributed to the operational challenges of undertaking research on food waste in HORECA as it is difficult, if not impossible, to separate food waste generated by tourists from the locals (Filimonau, Dickinson, Robbins, \& Reddy, 2013). More research on tourism's food waste is required which should aim at better understanding of 1) how much food waste is generated by tourists in comparison to the locals and to their at-home food consumption; 2) what fractions of food are wasted the most by tourists; and 3) the drivers of wastage among tourists. Better understanding of the magnitude of food waste generated in the tourism context, the major fractions of wasted food and the key contributing factors will enable the design of more effective measures to food waste reduction (Koivupuro, et al., 2012; Silvennoinen, Katajajuuri, Hartikainen, Heikkila, 
\& Reinikainen, 2014; Thyberg \& Tonjes, 2016).

Food waste mitigation is an important sustainability objective in China, a populous country with limited natural resources (L. E. Wang, et al., 2017). Domestic tourism in China is growing rapidly and so are the related environmental externalities, such as food waste (Y. Y. Li, Filimonau, Wang, \& Cheng, 2020). It is therefore necessary to have an in-depth understanding of the reasons why tourists in China waste food, thus identifying feasible approaches to mitigation (Cheng et al., 2018). The topic of tourism's food waste in China has however been overlooked to-date. Past research has estimated food waste in the national HORECA sector and provided an initial insight into the contribution made by tourism (L. E. Wang, et al., 2018). Past research has further highlighted some of the differences in food consumption behaviour of tourists on the tour and at home, including wastage (Y. Y. Li, Wang, \& Cheng, 2019), but no comprehensive outlook has ever been provided. This study will partially fill this important knowledge gap by exploring the patterns of food consumption, with a focus on wastage, among a sample of tourists in Lhasa, a popular destination in China. Lhasa represents a suitable case study to explore tourism's food waste because not only is it popular with domestic Chinese visitors, but also it has limited natural resources and fragile ecosystems (L. E. Wang, et al., 2018). To this end, the study aims to (i) estimate food wastage by domestic tourists and establish the composition of wasted food; (ii) determine the main behavioural determinants of food wastage among tourists; iii) provide recommendations on how food wastage by tourists could be reduced.

\section{Materials and Methods}

\subsection{Measurement tools and questionnaire design}

To fulfill the aim of this study, a self-completion questionnaire was developed for 
primary data collection. The questionnaire used the food waste rate (FWRE) and the food waste ratio (FWRO) to establish the magnitude of food wastage among tourists. FWRE set to reveal the percentage of remaining/uneaten food of the total ordered food and FWRO strove to disclose the percentage of each type of wasted food. The types of wasted food under study included grain, meat, vegetables, fruits, dairy products, aquatic products and drinks as these are the most commonly consumed foodstuffs by the Chinese which holds true for this study given its focus on domestic tourists. Previously, FWRE and FWRO have been used to identify food waste and its drivers in rural households (F. Li, Jiang, Zhu, \& Qian, 2017) and in the sector of foodservice provision in schools (Yoon \& Kim, 2012). These were preferred to the method of direct weighting due to the laborious (which includes high cost) nature of the latter as shown by (L. E. Wang, et al., 2018). Another reason for using FWRE and FWRO instead of the method of direct weighting in this study is the unwillingness of local restaurant managers in Lhasa to grant researchers permission to weigh food waste in their kitchens. Managerial reluctance to collaborate with academics on studying the challenge of food waste has long been recognised and attributed to the perceived business sensitivity of this topic (Filimonau, Krivcova, \& Pettit, 2019) which, as this study demonstrates, finds further confirmation in the context of China. The drawback of FWRE and FWRO is in that their results may deviate from the actual amounts of food wasted by tourists which is due to social desirability biases as well as the general problem of poor public recall of past events (of eating out). To minimise the negative effect of social desirability biases, the anonymous nature of this study was repeatedly emphasised at the stage of participant recruitment. To reduce the detrimental effect of poor recall, wherever possible, participant recruitment took place immediately after the eating out occasions, i.e. at lunch and/or dinner times.

The survey questionnaire included four sections (Fig. 1). The first section of the questionnaire aimed at collecting information on food consumption and waste behavior, thus estimating food wastage by tourists. To this end, six questions were 
asked:

(1a) On this trip to Lhasa, how much (by percentage) food was left on the plate you ordered, on average, for a meal? (FWRE); (1b) To the best of your recall, what was the composition of wasted food? Please divide wasted food into grain, meat, vegetables, fruits, eggs, dairy products, aquatic products and drinks by percentage (FWRO). (2a) When you cook at home, how much (by percentage) food is usually left on the plate you prepared, on average, for a meal? (FWRE); (2b) To the best of your recall, what was the composition of wasted food? Please divide wasted food into grain, meat, vegetables, fruits, eggs, dairy products, aquatic products and drinks by percentage (FWRO).

(3a) When you eat out in your place of permanent residence (not on this trip to Lhasa), how much (by percentage) food was left on the plate you ordered, on average, for a meal? (FWRE); (3b) To the best of your recall, what was the composition of wasted food? Please divide wasted food into grain, meat, vegetables, fruits, eggs, dairy products, aquatic products and drinks by percentage (FWRO).

\section{Socio-demographic characteristics of consumers alongside the levels of their} knowledge and perception of the challenge of food waste are important prerequisites of food waste generation (Aschemann-Witzel, et al., 2015; Filimonau, Matute, Kubal-Czerwińska, \& Krzesiwo, 2019; Thyberg \& Tonjes, 2016). Thus, the second section of the questionnaire aimed at acquiring tourists' socio-demographic characteristics, which included gender, age, education, family status, career stage, income, hometown and religion.

The third section aimed at acquiring tourists' perceptions on food consumption/waste. These were captured with the help of four statements/questions:

(1) I am still more accustomed to the cuisine and eating habits of my hometown 
(perceptions were recorded via Likert scale of 1-7 where 1 stood for strongly disagree and 7 stood for strongly agree);

(2) I know Tibetan cuisine very well (knowledge was recorded via Likert scale of 1-7 where 1 stood for strongly disagree and 7 stood for strongly agree).

(3) What do you think about the food (table) waste during the tour? (perceptions were captured via a dedicated scale of a-d, where a stood for I understand its occurrence because it is inevitable during the tour; b stood for I do not think this issue is serious although food indeed wasted during the tour; c stood for I think this is a serious issue and need to be recognised by various stakeholders; and d stood for I am not interested in this issue).

(4) Which of the following do you think is most relevant to table (food) waste prevention? (perceptions were captured via a multiple choice answer: a. government b. hotel/restaurant c. consumer d. others (HORECA industry management departments and HORECA industry associations)).

Further, tourists exemplify different consumption behavior patterns on different food consumption occasions, i.e. when cooking at home, when eating out and when on travel (Y. Y. Li, et al., 2019). It was assumed that the tourism situation (including duration of stay, the purpose of visit, companions and frequency of travel to the destination/familiarity) could impact the food waste behavior of tourists. To capture the effect of these factors, relevant measures were included in the fourth section of the questionnaire asking participants to provide basic information about their trip to Lhasa. 


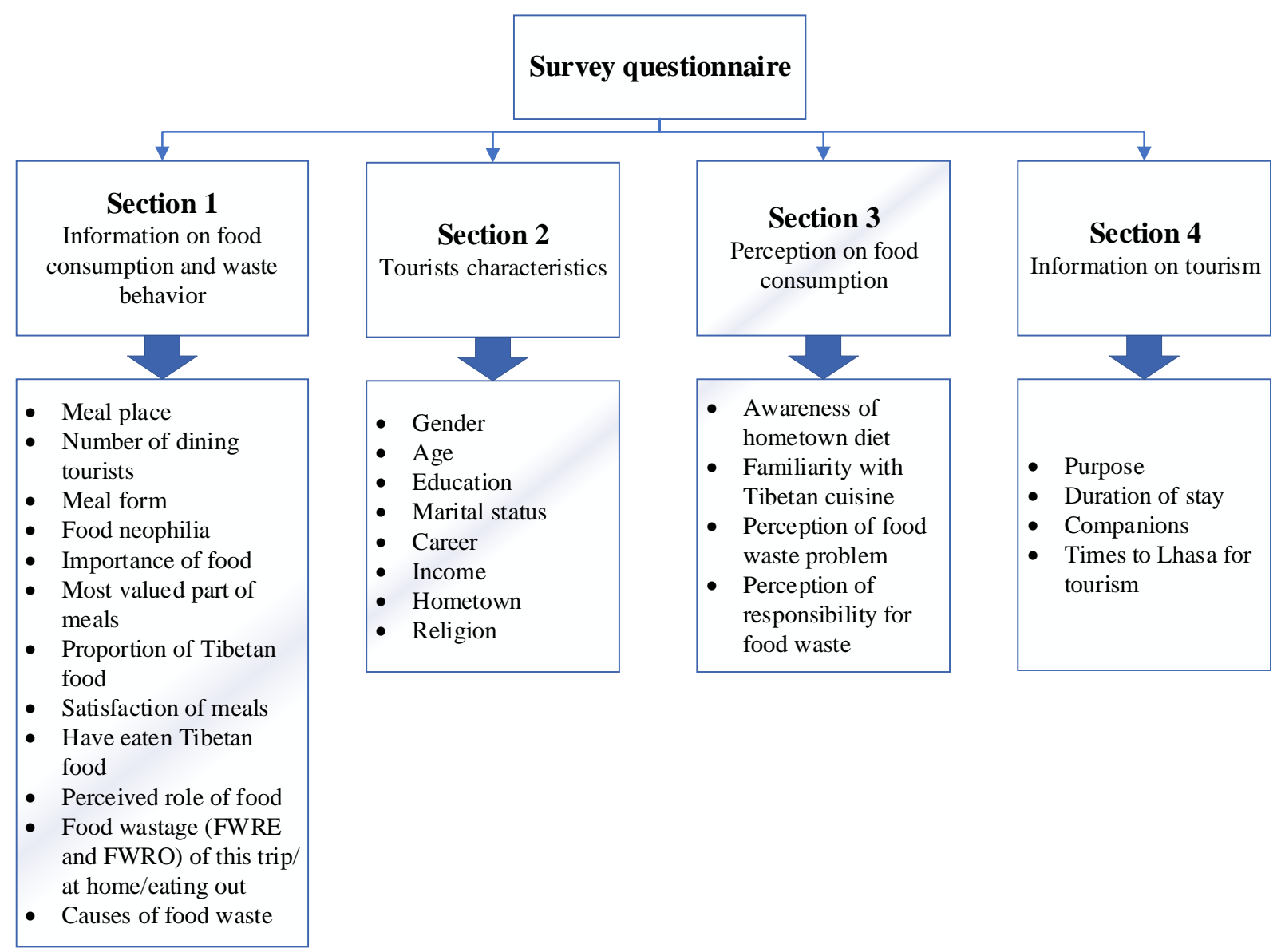

Fig. 1 Four sections of the questionnaire

Although self-completion questionnaires represent a popular tool to explore the phenomenon of food waste (Ghinea \& Ghiuta, 2019; van der Werf, Seabrook, \&

199 Gilliland, 2020), they have been criticised for their tendency to under- or over-estimate the magnitude of food wastage (Chung, 2008), thus prompting

201 inaccurate conclusions (Kormos \& Gifford, 2014). This notwithstanding, self-completion questionnaires are preferred by many academics (Elimelech, Ert, \& Ayalon, 2019) due to their cost-effectiveness, especially in comparison to such time-consuming and laborious method as direct weighting (van der Werf, et al., 2020).

205 Self-completion questionnaires are also capable of reaching for larger samples 206 (Zorpas \& Lasaridi, 2013), thus, leading to a better standardisation and improved robustness of analysis (Secondi, Principato, \& Laureti, 2015). Lastly, it is argued that 
self-completion questionnaires represent the only meaningful approach to capturing the magnitude of tourist food waste in HORECA. This is because most HORECA enterprises in a destination cater not only for tourists, but also for local residents. This implies that the method of direct weighting of food waste in a restaurant would be unable to separate the amounts of food wasted by tourists from wastage produced by the locals. This demonstrates the practical viability of the method of self-completion questionnaires and, hence, it was adopted in this study.

\subsection{Participant recruitment}

A stratified sampling method was used in the field survey to obtain sample tourists from August $25^{\text {th }}, 2018$ to September $4^{\text {th }}, 2018$. The survey was administered in popular tourist recreation spots in Lhasa such as the Potala Palace Square, the Jokhang Temple, the Sunshine Travel Bookstore, and the Zongjiao Lukang Park. Self-completion questionnaires were distributed by experienced researchers and college students trained in the given survey method. A total of 713 questionnaires were completed with an effective response rate of $93 \%$. As a basic screening criterion, the survey targeted only those domestic tourists who had stayed in Lhasa for at least one day and consumed food. In the case of family tourists, only one family member was invited to partake in the survey.

\subsection{Quantifying food waste and establishing its drivers}

Microsoft Excel 2016 and SATA 14 software were used to analyze the food waste characteristics and the drivers behind wastage. First, the composition of food waste revealed in the survey was evaluated through statistical analysis. Second, the FWRE values among different tourist groups were identified through a one-way ANOVA. Lastly, multiple linear regression analysis was conducted to evaluate the drivers of food wastage. To this end, the Tobit regression model (Y. Y. Li, et al., 2019; Zhang, et 
235 al., 2018) was employed to address the shortcomings of bias and inconsistency of 236 parameter estimates (Bone, 1995). The analytical framework utilised to achieve the 237 aims of this study is as follows:

239 The model built to establish the drivers of tourist food waste can be expressed as 240 follows:

$$
y_{i}=\alpha_{0}+\alpha_{1} x_{1 i}+\alpha_{2} x_{2 i}+\alpha_{3} x_{3 i}+\ldots+\alpha_{27} x_{27 i}+\varepsilon_{i}
$$

243

244 where the dependent variable $y_{i}$ denotes FWRE of tourist $i(i=1,2,3, \ldots, 713)$ and the 245 independent variables $x_{i}$ denote various factors affecting food waste behavior. These 246 factors can be grouped as follows: (i) socio-demographic characteristics: $x_{1 \sim} x_{8}$; (ii) 247 food consumption characteristics: $x_{9 \sim} x_{13}$; (iii) past experience: $x_{14 \sim} x_{15}$; (iv) tourism 248 motivation factor: $x_{16 \sim} x_{17}$; (v) other aspects of tourism: $x_{18 \sim} x_{27}$. All model variables 249 are explained in further detail in Table 1. 


\begin{tabular}{|c|c|c|c|c|}
\hline $\begin{array}{l}\text { Variable } \\
\text { category }\end{array}$ & Variable & Variable symbol & Variable definition & References \\
\hline & Dependent variable: & & & \\
\hline & Food waste rate & $F W R E$ & $\begin{array}{l}\text { The proportion of uneaten food in total ordered food } \\
\text { by tourist }(\%)\end{array}$ & $\begin{array}{l}\text { F. Li, et al. (2017) used FWRE to study } \\
\text { food waste and its drivers }\end{array}$ \\
\hline & Independent & & & \\
\hline & variables: & & & \\
\hline \multirow{7}{*}{$\begin{array}{l}\text { Demographic } \\
\text { characteristics }\end{array}$} & Gender $\left(x_{1}\right)$ & gender & $\begin{array}{l}\text { If the respondent is female, the value is equal to } 1 \text {, } \\
\text { otherwise is } 0 .\end{array}$ & $\begin{array}{l}\text { Painter, Thondhlana, \& Kua (2016) claim } \\
\text { that gender plays a role in food waste } \\
\text { generation }\end{array}$ \\
\hline & $\operatorname{Age}\left(x_{2}\right)$ & age & $\begin{array}{l}\text { 1: }<18 \text { years old; } 2: 18 \sim 25 \text { years old; } 3: 26 \sim 40 \text { years } \\
\text { old; 4: 41 50 years old; 5: 51 60 years old; } 6:>60 \\
\text { years old }\end{array}$ & $\begin{array}{l}\text { Zhang, et al. (2018) claim that age plays a } \\
\text { role in food waste generation }\end{array}$ \\
\hline & Family status $\left(x_{3}\right)$ & & & Koivupuro, et al. (2012) claim that family \\
\hline & $\begin{array}{l}\text { Married with } \\
\text { children }\end{array}$ & married_chr & $\begin{array}{l}\text { If the respondent married and has children, the value is } \\
\text { equal to } 1 \text {, otherwise is } 0\end{array}$ & $\begin{array}{l}\text { status is a potential factor influencing food } \\
\text { waste }\end{array}$ \\
\hline & $\begin{array}{l}\text { Married without } \\
\text { children }\end{array}$ & married_nochr & $\begin{array}{l}\text { If the respondent married and has no children, the } \\
\text { value is equal to } 1 \text {, otherwise is } 0\end{array}$ & \\
\hline & Unmarried & unmarried & $\begin{array}{l}\text { If the respondent is not married, the value is equal to } 1 \text {, } \\
\text { otherwise is } 0 \text { (control group) }\end{array}$ & \\
\hline & Education $\left(x_{4}\right)$ & education & $\begin{array}{l}\text { 1: primary school or below; } 2 \text { : junior high school; } 3 \text { : } \\
\text { high school/secondary school; 4: junior/high } \\
\text { vocational school; 5: undergraduate; } 6 \text { : postgraduate }\end{array}$ & $\begin{array}{l}\text { Zhang, et al. (2018) claim that educational } \\
\text { level plays a role in food waste generation }\end{array}$ \\
\hline
\end{tabular}


Career $\left(x_{5}\right)$

Public officials

State-owned

enterprise employees

Foreign company

employees

Private enterprise,

collective enterprise

employees

Self-employed

persons

Famers

Workers

Retired or staffs

without work

Students

Other careers

Income $\left(x_{6}\right)$ public_officials

employees

employees_for

employees_pri

self-employed

famers

workers

retired

students

career other

income
If the respondent's career is a public official, the value is equal to 1 , otherwise is 0

If the respondent's career is a state-owned enterprise employee, the value is equal to 1 , otherwise is 0

If the respondent's career is a foreign company-owned employee, the value is equal to 1 , otherwise is 0

If the respondent's career is a private enterprise or a

collective enterprise employee, the value is equal to 1 , otherwise is 0

If the respondent's career is a self-employed person,

the value is equal to 1 , otherwise is 0

If the respondent's career is a farmer, the value is

equal to 1 , otherwise is 0 (control group)

If the respondent's career is a worker, the value is

equal to 1 , otherwise is 0

If the respondent's career is retired or unemployed, the

value is equal to 1 , otherwise is 0

If the respondent's career is a student, the value is

equal to 1 , otherwise is 0

If the respondent's career is not included in the above

mentioned, the value is equal to 1 , otherwise is 0

Monthly income: 1: <4000 RMB; 2: 4000 5999 RMB; Zhang, et al. (2018) claim that the level of 3: 6000 7999 RMB; 4: 8000 9999 RMB; 5:

10000 11999 RMB; 6: 12000 13999 RMB; 7:

14000-15999 RMB; 8: >16000 RMB
Koivupuro, et al. (2012) claim that career is a potential factor influencing food waste 
Religion belief $\left(x_{7}\right) \quad$ If the respondent has religion, the value is equal to 1,
otherwise is 0

Local $\left(x_{8}\right)$

local

If the respondent is the local resident of Tibet, the value is equal to 1 , otherwise is 0

\section{Food neophilia $\left(x_{9}\right) \quad$ neophilia}

Importance of food

$\left(x_{10}\right)$

Food

consumption

characteristics

Most valued part of

meals $\left(x_{11}\right)$

Taste

Appearance

Volume

Price taste

appearance

volume

importance_food

If the respondent is prepared to taste unfamiliar food, the value is equal to 1 , otherwise is 0

The importance value (1 6) of "food" in six elements of tourism (food, accommodation, transportation, sightseeing, shopping, and entertainment)

If the respondent most valued the taste of food on this tour, the value is equal to 1 , otherwise is 0 (control group)

If the respondent most valued the appearance matching of food on this tour, the value is equal to 1 , otherwise is 0

If the respondent most valued the amount of food on this tour, the value is equal to 1 , otherwise is 0

If the respondent most valued the price of food on this
Mak, Lumbers, Eves, \& Chang (2012);

Pettinger, Holdsworth, \& Gerber (2004) and Suki \& Suki (2015) claim that religion plays a role in food consumption behavior, including waste generation

L. E. Wang, et al., (2018) finds that tourists waste more food than the local residents of Lhasa

Mak, et al. (2012) and Mak, Lumbers,

Eves, \& Chang (2013) claim that food neophilia and neophobia affect tourist food consumption, including waste generation

Mak, et al. (2012) claim that motivational factors to try food affect tourist food consumption

Mak, et al. (2012) claim that sensory attributes (e.g., flavour, aroma, texture, appearance), price, value, and quality of food in the destination affect tourist food consumption 
trip, the value is equal to 1 , otherwise is 0

\begin{tabular}{|c|c|c|}
\hline Nutrition & nutrition & $\begin{array}{l}\text { If the respondent most valued the nutrition of food on } \\
\text { this trip, the value is equal to } 1 \text {, otherwise is } 0\end{array}$ \\
\hline Health & health & $\begin{array}{l}\text { If the respondent most valued the health of food on } \\
\text { this trip, the value is equal to } 1 \text {, otherwise is } 0\end{array}$ \\
\hline Other aspects & food_other & $\begin{array}{l}\text { If the respondent most valued the other aspects of food } \\
\text { other than above mentioned (e.g. smell, local cuisine } \\
\text { characteristics) on this trip, the value is equal to } 1 \text {, } \\
\text { otherwise is } 0\end{array}$ \\
\hline
\end{tabular}

Proportion of

Tibetan food $\left(x_{12}\right)$

proportion_local

The proportion of consumption of Tibetan food on this

$\operatorname{trip}(\%)$

Personal satisfaction with the meals served on this trip:

Satisfaction of meals

$\left(x_{13}\right)$

meal_satisfaction

1: very dissatisfied; 2 : dissatisfied; 3 : partially

dissatisfied; 4: neutral; 5: partially satisfied; 6 :

satisfied; 7: very satisfied

\begin{tabular}{|c|c|c|c|}
\hline Past & $\begin{array}{l}\text { Travel times to } \\
\text { Lhasa }\left(x_{14}\right)\end{array}$ & times & $\begin{array}{l}\text { If the respondent traveled to Lhasa for the first time, } \\
\text { the value is equal to } 1 \text {, otherwise is } 0\end{array}$ \\
\hline experience & $\begin{array}{l}\text { Have eaten Tibetan } \\
\text { food }\left(x_{15}\right)\end{array}$ & food_tib & $\begin{array}{l}\text { If the respondent has ever eaten a Tibetan meal before, } \\
\text { the value is equal to } 1 \text {, otherwise is } 0\end{array}$ \\
\hline
\end{tabular}

Travel purpose $\left(x_{16}\right)$

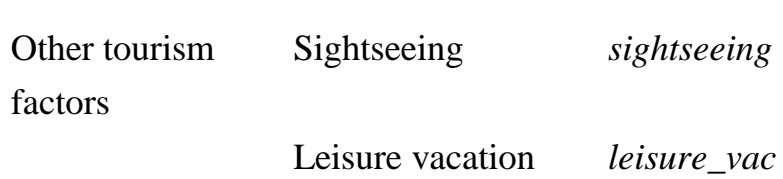

If the main purpose of this trip includes sightseeing,

the value is equal to 1 , otherwise is 0

If the main purpose of this trip includes leisure

vacation, the value is equal to 1 , otherwise is 0

Mak, et al. (2012) claim that food/cuisine type (e.g., national/regional/local cuisine) affect tourist food consumption

Carvalho, Lima, \& Rocha (2015) claim that high FWRE suggest customer's dissatisfaction with the meal

Zhang, et al. (2018) claim that frequency of meal consumption occasions plays a role in food wastage; Mak, et al. (2012) claim that past experience of food affects tourist food consumption

Mak, et al. (2012) claim that motivational factors to go on a holiday affect tourist food consumption 


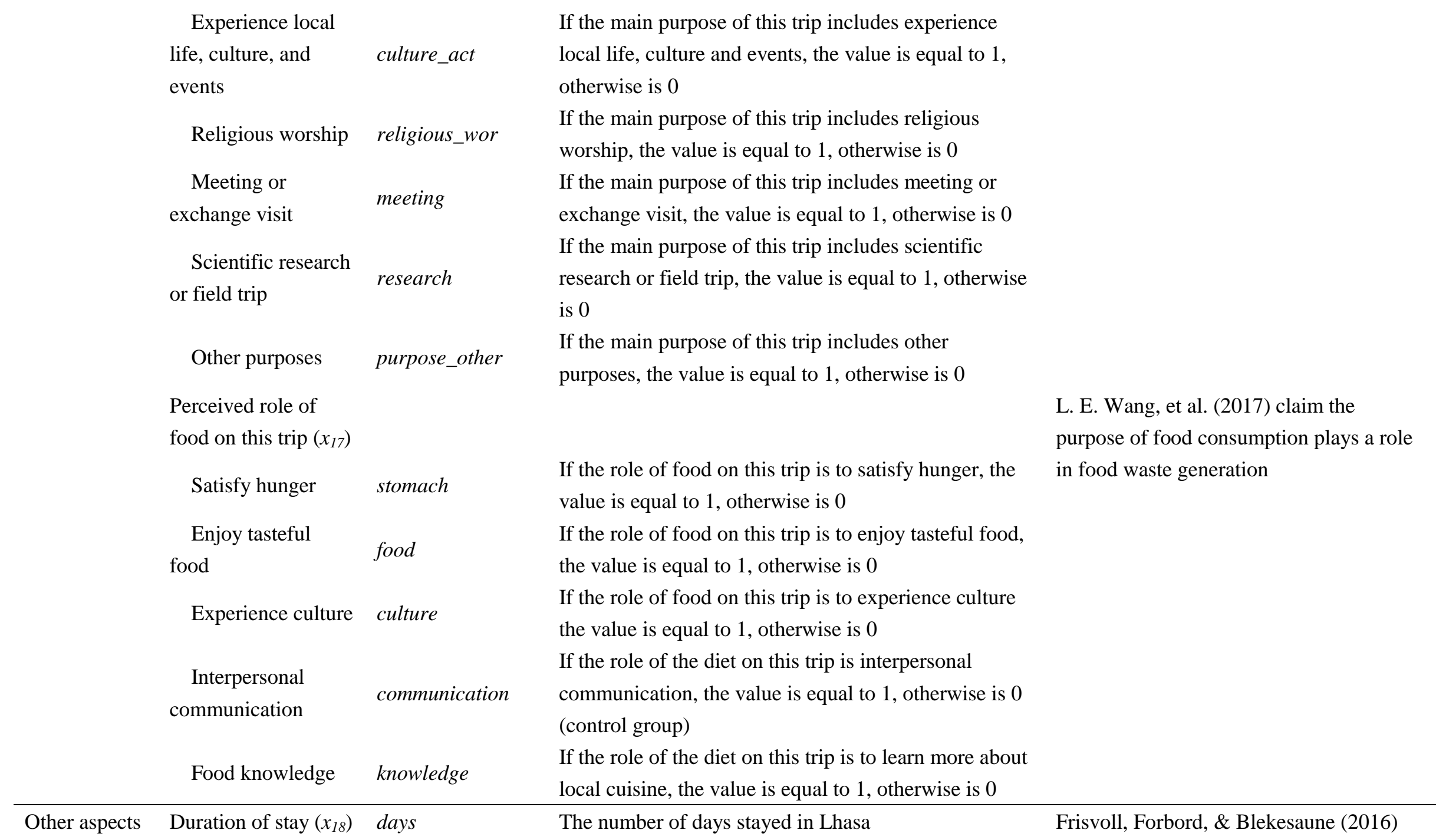




\section{0-year-old tourist}

companion $\left(x_{19}\right)$

18-year-old tourist

companion $\left(x_{20}\right)$

Meal place $\left(x_{21}\right)$

Specialty snack

bar

Ordinary

restaurant

Restaurant

specializing in

catering for tourist

groups

\section{Star Hotels \\ Relatives' or}

friends' home

Other places

Number of dining

tourists $\left(x_{22}\right)$ companion_50

companion_18

snack

ordinary

fixed

hotel

friends

location_other

number_tou
If there are companions over 50 years old on this trip

in Lhasa, the value is equal to 1 , otherwise is 0

If there are companions under 18 years old on this trip in Lhasa, the value is equal to 1 , otherwise is 0

If the main meal place on this trip is specialty snack bar, the value is equal to 1 , otherwise is 0

If the main meal place on this trip is ordinary restaurant, the value is equal to 1 , otherwise is 0

If the main meal place on this trip is restaurant specializing in catering for tourist groups, the value is equal to 1 , otherwise is 0 (control group)

If the main meal place on this trip is star hotels, the value is equal to 1 , otherwise is 0

If the main meal place on this trip is relatives' or friends' home, the value is equal to 1 , otherwise is 0 If the main meal place on this trip is other places, the value is equal to 1 , otherwise is 0

The average number of people have meals together on this trip affects tourist consumption of local food

Frisvoll, et al. (2016) claim that travelling

companions affect tourist consumption of

local food; Mak, et al. (2012) claim that

contextual influences (e.g., time, place,

companionship) affect tourist food

consumption

Mak, et al. (2012) claim that contextual

influences (e.g., time, place,

companionship) affect tourist food

consumption; S. K. Cheng, et al. (2018)

claim that a type of restaurants plays a role

in food waste generation

Stancu, Haugaard, \& Lahteenmaki (2016)

claim that household food waste behavior

significantly correlates with household 
Meal form $\left(x_{23}\right)$

\section{Table}

table

Buffet

buffet

Order

order

\section{Hometown diet $\left(x_{24}\right) \quad$ home_food}

Familiarity with

Tibetan cuisine $\left(x_{25}\right)$

tibetan_food

Tourism food

waste

perception

Waste degree $\left(x_{26}\right)$

\section{Understand}

understand

Not serious

not_serious

Serious

serious size (number of family members)

Juvan, Grun, \& Dolnicar (2018) claim that

If the main meal form on this trip is unified table meal, the value is equal to1, otherwise is 0

tourists waste more food during buffet

meals

If the main meal form on this trip is buffet, the value is

equal to 1 , otherwise is 0 (control group)

If the main meal form on this trip is order meal, the value is equal to 1 , otherwise is 0

The perception that "I am still more accustomed to the cuisine and eating habits of my hometown": 1 :

strongly disagree; 2 : disagree; 3 : partially disagree; 4 : neutral; 5: partially agree; 6: agree; 7: strongly agree The perception that "I know Tibetan cuisine very well": 1 : strongly disagree; 2 : disagree; 3 : partially disagree; 4: neutral; 5: partially agree; 6: agree; 7: strongly agree

If the respondent understands the problem of table (food) waste on the tour, the value is equal to 1 , otherwise is 0 (control group)

If the respondent thinks the problem of table (food)

waste on the tour is not serious, the value is equal to 1 , otherwise is 0

If the respondent thinks the problem of table (food) waste on the tour is serious and need to advocate conservation, the value is equal to 1 , otherwise is 0
Wu, Raab, Chang, \& Krishen (2016) claim that attitudes to unfamiliar local foodstuffs play a role in tourist food consumption behavior towards local food

Getlinger, Laughlin, Bell, Akre, \&

Arjmandi (1996) claim that familiarity with food correlates with the scale of food consumption

L. E. Wang, et al. (2017) and Zhang, et al. (2018) claim that awareness of food waste problem (frugality) plays a role in food waste generation; Aschemann-Witzel et al. (2015) claim that consumers' lack of awareness and knowledge of food waste plays a role in food waste generation 
Disinterest

disinterest

Waste responsibility

$\left(x_{27}\right)$

Government

government

Restaurant

restaurant

Customer

customer

Others
If the respondent does not pay much attention to the problem of table (food) waste on the tour, the value is equal to 1 , otherwise is 0

If the respondent believes that the table (food) waste prevention is most related to the government, the value is equal to 1 , otherwise is 0

If the respondent believes that the table (food) waste prevention is most related to the restaurant managers, the value is equal to 1 , otherwise is 0

If the respondent believes that the table (food) waste prevention is most related to the customers, the value is equal to 1 , otherwise is 0

If the respondent believes that the table (food) waste prevention is most related to the others (e.g. HORECA

relationship_other industry management departments and HORECA

industry associations), the value is equal to 1 ,
Aschemann-Witzel, et al. (2015) claim that consumers' lack of awareness and knowledge of food waste plays a role in food waste generation; Falasconi, et al. (2019) claim that consumers hardly recognize their responsibility for food waste generation when eating out; Parizeau, von Massow, \& Martin (2015) claim that individuals bear the primary responsibility for food waste reduction 
256 The average FWRE/FWRO of a tourist in Lhasa is the arithmetic mean of

257 FWRE/FWRO of all tourists, which can be expressed as:

$$
A F W R E=\frac{\sum_{i=1}^{n} F W R E_{i}}{n}
$$

$$
A F W R O_{j}=\frac{\sum_{i=1}^{n} F W R O_{i j}}{n}
$$

where AFWRE is the average FWRE of a tourist in Lhasa, $F W R E_{i}$ is the FWRE of a tourist $i(i=1,2,3, \ldots, 713) ; A F W R O_{j}$ is the average FWRO of a food type $j(j$ denotes grain, meat, vegetables, fruits, dairy products, aquatic products, and drinks, respectively) of a tourist; $F W R O_{i j}$ is the FWRO of a food type $j$ of a tourist $i$ ( $i=$ $1,2,3, \ldots, 713) ; n$ is the total number of tourists.

\section{Results}

\subsection{Tourist sample profile}

268 The socio-demographic profile of study participants is presented in Table 2. The sample is dominated by males $(59.89 \%)$ whose proportion is higher than that of the nation's average (51.13\%) (National Bureau of Statistics of China, 2019). This can be partially explained by that males, as household heads, took responsibility for responding to a survey in the case of family tourists. More than half of study informants were aged 26 40 years old which is more than two times the proportion of the national population aged 25 39 years (23.41\%) (National Bureau of Statistics of China, 2019). Popularity of Lhasa with business travelers (who are, in turn, are represented by young professionals) and students can partially explain this sample's deviation from the nation's average. Nearly $90 \%$ tourists are of Han nationality, which 
278 is consistent with the nation's overall ethnic distribution $(91.51 \%$, (Population Census

279 Office under the State Council of China \& National Bureau of Statistics of China,

280 2012). A quarter of tourists have a monthly income between 6000 to $7999 \mathrm{RMB}$. The

281 high consumption of tourism (Z. C. Wang \& Li, 2006) determined that tourists'

282 income is usually higher than that of the nation's average disposable income (2352

283 RMB in 2018) (National Bureau of Statistics, 2020). Most study participants

284 represented employees of private enterprises and collective enterprises (23.42\%),

285 public officials (16.27\%), and students (15.01\%). Nearly half of respondents are

286 educated to a bachelor's degree. More than half are unmarried tourists and $38.85 \%$

287 have children.

288

289

Table 2. Socio-demographic profile of study participants

\begin{tabular}{|c|c|c|c|c|c|c|c|}
\hline Category & Classification & $\begin{array}{c}\text { Numbe } \\
r\end{array}$ & $\begin{array}{c}\text { Proportion } \\
\%\end{array}$ & Category & Classification & Number & $\begin{array}{c}\text { Proportion } \\
\%\end{array}$ \\
\hline \multirow{3}{*}{ Gender } & Male & 427 & 59.89 & \multirow{10}{*}{ Career } & Public officials & 116 & 16.27 \\
\hline & Female & 286 & 40.11 & & $\begin{array}{l}\text { State-owned } \\
\text { enterprise } \\
\text { employees }\end{array}$ & 55 & 7.71 \\
\hline & $<18$ & 6 & 0.84 & & $\begin{array}{c}\text { Foreign company } \\
\text { employees }\end{array}$ & 44 & 6.17 \\
\hline \multirow{5}{*}{ Age } & $18-25$ & 202 & 28.33 & & $\begin{array}{l}\text { Private enterprise } \\
\text { and collective } \\
\text { enterprise } \\
\text { employees }\end{array}$ & 167 & 23.42 \\
\hline & $26-40$ & 395 & 55.40 & & $\begin{array}{l}\text { Self-employed } \\
\text { persons }\end{array}$ & 104 & 14.59 \\
\hline & $41-50$ & 81 & 11.36 & & Famers & 28 & 3.93 \\
\hline & $51-60$ & 19 & 2.66 & & Workers & 44 & 6.17 \\
\hline & $>60$ & 10 & 1.40 & & $\begin{array}{l}\text { Retired and staffs } \\
\text { without work }\end{array}$ & 36 & 5.05 \\
\hline \multirow{2}{*}{ Nationality } & Han nationality & 623 & 87.38 & & Students & 107 & 15.01 \\
\hline & Minority & 80 & 12.62 & & Other careers & 12 & 1.68 \\
\hline \multirow{3}{*}{$\begin{array}{l}\text { Income } \\
\text { (RMB) }\end{array}$} & $<4000$ & 168 & 23.56 & \multirow{3}{*}{ Education } & $\begin{array}{c}\text { Elementary school } \\
\text { or below }\end{array}$ & 13 & 1.82 \\
\hline & $4000-5999$ & 164 & 23.00 & & Junior high school & 56 & 7.85 \\
\hline & $6000-7999$ & 174 & 24.40 & & $\begin{array}{c}\text { High } \\
\text { school/secondary }\end{array}$ & 104 & 14.59 \\
\hline
\end{tabular}




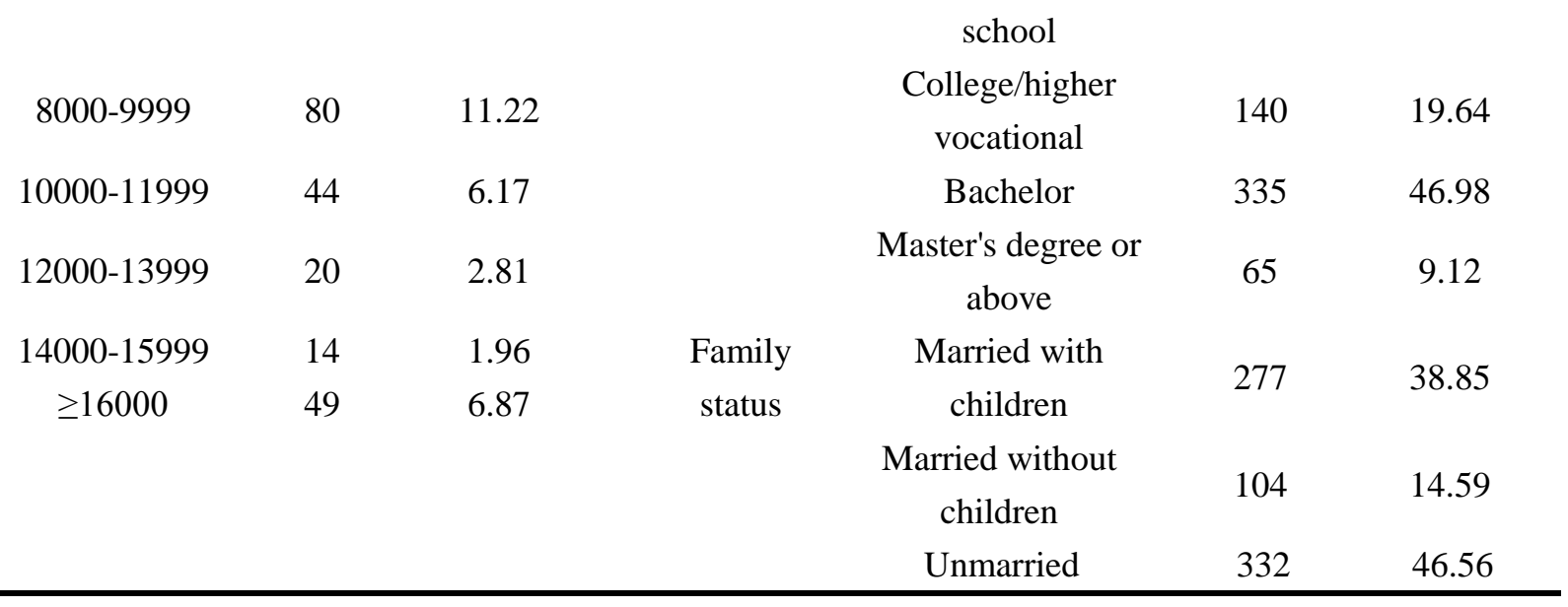

290

291 Descriptive statistics of the model variables are summarized in Table 3. The main

292 points that can be derived from it are as follows:

293

294 Within the sample, the FWRE values range from 0 to $90 \%$. Among the six elements

295 of tourism (food, accommodation, transportation, sightseeing, shopping,

296 entertainment), tourists tend to rank "food" as the third most important element of

297 their visit to Lhasa (mean value of importance_food variable is 2.823). They had

298 about $24 \%$ of meals from the Tibetan cuisine on average. On this tour, respondents

299 expressed their partial satisfaction with their meals. On average, their trips to Lhasa

300 lasted about 6.9 days and usually, when eating out, they had 3 meal companions.

301 Respondents partially agree with the statement that "I am still more accustomed to the

302 cuisine and eating habits of my hometown". In comparison, tourists in Lhasa think the

303 table (food) waste problem in the tour is not serious and believe the prevention of

304 food waste issue is mostly related to the customers (restaurant visitors). The common

305 opinion is that restaurant guests should aim at reducing the amounts of food waste

306 generated.

307

308

Table 3. Descriptive statistics of model variables

\begin{tabular}{lcrrrr}
\hline Variable & Obs & Mean & Std.Dev. & Min & Max \\
\hline FWRE & 713 & 14.64 & 13.965 & 0 & 90 \\
gender & 713 & 0.401 & 0.49 & 0 & 1 \\
age & 713 & 2.909 & 0.81 & 1 & 6
\end{tabular}




\begin{tabular}{|c|c|c|c|c|}
\hline$a g e \_s q$ & 713 & 9.116 & 5.501 & 1 \\
\hline married_chr & 713 & 0.388 & 0.488 & 0 \\
\hline married_nochr & 713 & 0.146 & 0.353 & 0 \\
\hline unmarried & 713 & 0.466 & 0.499 & 0 \\
\hline educaton & 713 & 4.295 & 1.172 & 1 \\
\hline educaton_sq & 713 & 19.815 & 9.091 & 1 \\
\hline public_officials & 713 & 0.163 & 0.369 & 0 \\
\hline employees & 713 & 0.077 & 0.267 & 0 \\
\hline employees_for & 713 & 0.062 & 0.241 & 0 \\
\hline employees_pri & 713 & 0.234 & 0.424 & 0 \\
\hline self-employed & 713 & 0.146 & 0.353 & 0 \\
\hline farmer & 713 & 0.039 & 0.194 & 0 \\
\hline workers & 713 & 0.062 & 0.241 & 0 \\
\hline retired & 713 & 0.05 & 0.219 & 0 \\
\hline students & 713 & 0.15 & 0.357 & 0 \\
\hline career_other & 713 & 0.017 & 0.129 & 0 \\
\hline income & 713 & 3.041 & 1.954 & 1 \\
\hline religion & 713 & 0.196 & 0.398 & 0 \\
\hline ethnic & 713 & 0.874 & 0.332 & 0 \\
\hline local & 713 & 0.079 & 0.269 & 0 \\
\hline neophilia & 713 & 0.741 & 0.439 & 0 \\
\hline importance_food & 713 & 2.823 & 1.508 & 1 \\
\hline taste & 713 & 0.324 & 0.468 & 0 \\
\hline appearance & 713 & 0.021 & 0.144 & 0 \\
\hline volume & 713 & 0.032 & 0.177 & 0 \\
\hline price & 713 & 0.107 & 0.309 & 0 \\
\hline nutrition & 713 & 0.087 & 0.282 & 0 \\
\hline health & 713 & 0.426 & 0.495 & 0 \\
\hline food_other & 713 & 0.003 & 0.053 & 0 \\
\hline proportion_local & 713 & 24.165 & 19.859 & 0 \\
\hline meal_satisfation & 713 & 4.976 & 1.017 & 1 \\
\hline times & 713 & 0.541 & 0.499 & 0 \\
\hline sightseeing & 713 & 0.663 & 0.473 & 0 \\
\hline leisure_vac & 713 & 0.516 & 0.5 & 0 \\
\hline culture_act & 713 & 0.39 & 0.488 & 0 \\
\hline religious_wor & 713 & 0.08 & 0.271 & 0 \\
\hline meeting & 713 & 0.062 & 0.241 & 0 \\
\hline research & 713 & 0.029 & 0.169 & 0 \\
\hline purpose_other & 713 & 0.024 & 0.153 & 0 \\
\hline food_tib & 713 & 0.488 & 0.5 & 0 \\
\hline stomach & 713 & 0.149 & 0.356 & 0 \\
\hline food & 713 & 0.257 & 0.437 & 0 \\
\hline culture & 713 & 0.509 & 0.5 & 0 \\
\hline communication & 713 & 0.06 & 0.238 & 0 \\
\hline
\end{tabular}




\begin{tabular}{lrrrrr} 
knowledge & 713 & 0.025 & 0.157 & 0 & 1 \\
days & 713 & 6.914 & 7.183 & 1 & 90 \\
companion_50 & 713 & 0.143 & 0.35 & 0 & 1 \\
companion_18 & 713 & 0.107 & 0.309 & 0 & 1 \\
number_tou & 713 & 3.266 & 2.383 & 1 & 23 \\
snack & 713 & 0.321 & 0.467 & 0 & 1 \\
ordinary & 713 & 0.52 & 0.5 & 0 & 1 \\
fixed & 713 & 0.063 & 0.243 & 0 & 1 \\
hotel & 713 & 0.046 & 0.21 & 0 & 1 \\
friends & 713 & 0.036 & 0.188 & 0 & 1 \\
location_other & 713 & 0.013 & 0.112 & 0 & 1 \\
table & 713 & 0.222 & 0.416 & 0 & 1 \\
order & 713 & 0.717 & 0.451 & 0 & 1 \\
buffet & 713 & 0.062 & 0.241 & 0 & 1 \\
home_food & 713 & 5.08 & 1.494 & 1 & 7 \\
tibetan_food & 713 & 3.801 & 1.587 & 1 & 7 \\
understand & 713 & 0.126 & 0.332 & 0 & 1 \\
not_serious & 713 & 0.415 & 0.493 & 0 & 1 \\
serious & 713 & 0.342 & 0.475 & 0 & 1 \\
disinterest & 713 & 0.116 & 0.321 & 0 & 1 \\
gevonerment & 713 & 0.056 & 0.23 & 0 & 1 \\
restarurant & 713 & 0.261 & 0.439 & 0 & 1 \\
customer & 713 & 0.676 & 0.468 & 0 & 1 \\
relationshop_other & 713 & 0.007 & 0.084 & 0 & 1 \\
\hline
\end{tabular}

\subsection{Reliability and validity test}

311 The reliability test returned the Cronbach $\alpha$ value of 0.944 , indicating that the 312 reliability of the scale and the consistency of measurement indicators are both high 313 (Davenport, Davison, Liou, \& Love, 2015); the KMO value was 0.952 and the results 314 of the spherical test were significant $(\mathrm{P}=0.000)$, indicating the structural validity of the 315 questionnaire was good (Sekaran, 2003; Vitasari, Wahab, Herawan, Othman, \& 316 Sinnadurai, 2011). 


\subsubsection{Food waste composition}

319 On average, the tourist FWRE in Lhasa is $14.64 \%$. Statistically, it is significantly $320(\mathrm{P}<0.01$, Table 4$)$ higher than the tourist FWRE $(8.43 \%)$ in the at-home context. 321 Among 713 tourists, $10 \%$ stated they did not generate food waste on this trip; more than half wasted 1\% 10\% food; $20 \%$ tourists wasted food at the rate of $11 \%$ 20\% 323 and $15 \%$ wasted $21 \%$ 50\%; only $2 \%$ respondents expressed that they wasted more than $50 \%$ (Fig. 2a). As to the food waste composition, the proportion of grain is the 325 largest (30\%), followed by meat (24\%) and vegetables (16\%); the wastage of fruits, drinks, dairy products, aquatic products and eggs is insignificant (Fig. 2b). Tourists'

327 FWRO of grain is substantially lower than that in the at-home context, while the

328 FWROs of meat and drinks are significantly higher $(\mathrm{P}<0.01$, Table 4$)$.

Table 4. Paired t-test of tourist FWRE and FWRO in the contexts of tourism and at 331 home

\begin{tabular}{ccccc}
\hline Food type & Obs & $\begin{array}{c}\text { Tourism } \\
\text { Mean } \\
(\text { Std.Dev })\end{array}$ & At-home Mean & $\begin{array}{c}\text { Difference of } \\
\text { Tourism vs. } \\
\text { At-home } \\
(\text { Std.Err) }\end{array}$ \\
\hline All food & 713 & 14.64 & 8.43 & $6.21^{* * *}$ \\
Grain & 524 & $(13.96)$ & $(9.48)$ & $(0.53)$ \\
& & $(29.14)$ & $(26.14)$ & $-6.01 * * *$ \\
Meat & 524 & 24.40 & 19.08 & $5.32^{* * *}$ \\
& & $(21.86)$ & $(17.52)$ & $(1.00)$ \\
Vegetables & 524 & 15.84 & 16.89 & -1.05 \\
& & $(14.44)$ & $(15.05)$ & $(0.77)$ \\
Fruits & 524 & $(7.43)$ & $(7.50)$ & 0.24 \\
& & 5.20 & $0.39)$
\end{tabular}




\begin{tabular}{ccccc} 
& & 5.58 & 5.46 & 0.12 \\
Eggs & 524 & $(9.63)$ & $(6.93)$ & $(0.45)$ \\
& & 5.31 & 4.93 & 0.37 \\
Milk & 524 & $(7.59)$ & $(7.12)$ & $(0.35)$ \\
& & 5.61 & 6.16 & -0.55 \\
Aquatic & 524 & $(9.24)$ & $(10.25)$ & $(0.48)$ \\
products & & 7.34 & 5.77 & $1.57^{* * *}$ \\
& & $(11.95)$ & $(9.24)$ & $(0.57)$ \\
Drink & 524 & & & \\
\hline
\end{tabular}

a

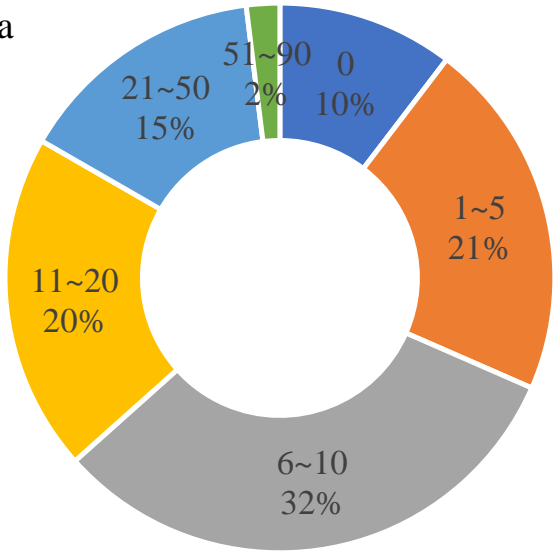

b

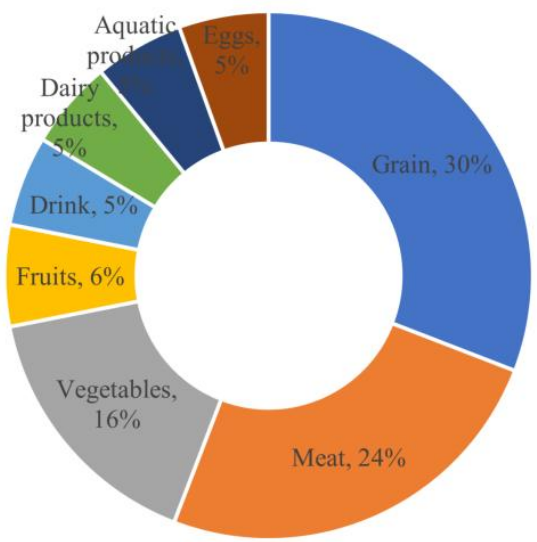

Fig. 2. (a) FWRE values stated by tourists (\%) (b) Composition of wasted food

338 The difference in food waste (FWRE or FWRO) can be seen among different tourist 339 groups (Table 5): (i) for different gender groups, compared with males, FWRE of 340 female tourists is significant higher $(\mathrm{P}<0.01)$ which is also the case for FWROs of 341 grain, vegetables and eggs $(\mathrm{P}<0.05, \mathrm{P}<0.05, \mathrm{P}<0.01$, respectively) for female tourists; 342 (ii) for different age groups, FWRE and FWRO of grain of tourists aged under 18 343 years old or above 50 years old is significantly lower than for other age groups $(\mathrm{P}<0.1$, $344 \mathrm{P}<0.1$, respectively), while FWRO of fruits and aquatic products of tourists aged under 18 years old is significantly higher than that for other age groups $(\mathrm{P}<0.05$, 
$346 \mathrm{P}<0.05$, respectively); (iii) FWRO of grain and aquatic products both have significant 347 differences among different career groups $(\mathrm{P}<0.1, \mathrm{P}<0.1$, respectively): workers have 348 the highest values of FWRO of grain and foreign company employees have the 349 highest values of FWRO of aquatic products; (iv) tourists with different education 350 levels have significant differences in FWRE and FWRO of vegetables $(\mathrm{P}<0.05$, $351 \mathrm{P}<0.01$, respectively): tourists educated to a bachelor's degree level have the highest 352 values of FWRE and tourists with an educational level of junior high school 353 exemplify the highest values of FWRO for vegetables; (v) respondents with different 354 family statuses show significantly different FWROs of meat and aquatic products $355(\mathrm{P}<0.05, \mathrm{P}<0.1$, respectively): married without children tourists have the highest 356 values of FWRO for meat while unmarried tourists show the highest values of FWRO 357 for aquatic products. 
Table 5. FWRE and FWRO among different tourist groups

\begin{tabular}{|c|c|c|c|c|c|c|c|c|c|c|c|c|c|c|c|c|c|c|c|}
\hline \multirow{2}{*}{$\begin{array}{c}\text { Categor } \\
\mathrm{y}\end{array}$} & \multirow{2}{*}{ Classification } & \multicolumn{2}{|c|}{ FWRE } & \multicolumn{2}{|c|}{ Grain } & \multicolumn{2}{|c|}{ Meat } & \multicolumn{2}{|c|}{ Vegetables } & \multicolumn{2}{|c|}{ Fruits } & \multicolumn{2}{|c|}{ Eggs } & \multicolumn{2}{|c|}{ Milk } & \multicolumn{2}{|c|}{$\begin{array}{l}\text { Aquatic } \\
\text { products }\end{array}$} & \multicolumn{2}{|c|}{ Drinks } \\
\hline & & $\begin{array}{l}\text { mea } \\
\mathrm{n}\end{array}$ & $\mathrm{F}$ & $\begin{array}{l}\text { mea } \\
\mathrm{n}\end{array}$ & $\mathrm{F}$ & $\begin{array}{l}\text { mea } \\
\mathrm{n}\end{array}$ & $\mathrm{F}$ & mean & $\mathrm{F}$ & $\begin{array}{l}\text { mea } \\
\mathrm{n}\end{array}$ & $\mathrm{F}$ & $\begin{array}{l}\text { mea } \\
\mathrm{n}\end{array}$ & $\mathrm{F}$ & $\begin{array}{l}\text { mea } \\
\mathrm{n}\end{array}$ & $\mathrm{F}$ & $\begin{array}{l}\text { mea } \\
\mathrm{n}\end{array}$ & $\mathrm{F}$ & $\begin{array}{l}\text { mea } \\
\mathrm{n}\end{array}$ & $\mathrm{F}$ \\
\hline \multirow{3}{*}{ Gender } & Male & $\begin{array}{r}13.4 \\
0\end{array}$ & $\begin{array}{l}8.47 * \\
* *\end{array}$ & 28.9 & $\begin{array}{l}6.45 \\
* *\end{array}$ & 21.0 & \multirow[t]{2}{*}{1.29} & \multirow[t]{2}{*}{15.09} & $5.25^{*}$ & \multirow[t]{2}{*}{5.45} & 0.01 & \multirow[t]{2}{*}{4.05} & $7.51^{*}$ & \multirow[t]{2}{*}{4.39} & 1.6 & \multirow[t]{2}{*}{4.77} & \multirow[t]{2}{*}{0.00} & \multirow[t]{2}{*}{6.41} & 1.6 \\
\hline & \multirow[b]{2}{*}{ Female } & 0 & & 4 & & 020 & & & & & & & & & 4 & & & & \\
\hline & & $\begin{array}{r}10.4 \\
0\end{array}$ & & $\begin{array}{r}24.1 \\
8\end{array}$ & & 25.0 & & 12.56 & & 5.40 & & \multirow[t]{2}{*}{5.96} & & 5.24 & & 4.81 & & 7.65 & \\
\hline \multirow{10}{*}{ Age } & \multirow{2}{*}{$<18$} & & & & & 155 & 2.08 & & & & & & & 11.6 & 1.5 & 15.0 & $2.58 *$ & 108 & 1.5 \\
\hline & & 7.67 & $2.11^{*}$ & 0 & 1.38 & 0 & $*$ & 10.00 & 1.15 & 3 & $* *$ & 9.17 & 1.31 & 7 & 4 & 0 & $*$ & 3 & 6 \\
\hline & 18,25 & 15.1 & & 26.5 & & 19.9 & & 13. & & 570 & & 544 & & 400 & & 5.4 & & 720 & \\
\hline & $10-2 J$ & 7 & & 1 & & 4 & & 15.14 & & 3.19 & & 3.44 & & 4.99 & & 3.41 & & 1.09 & \\
\hline & $26-40$ & 15.3 & & 26.8 & & 23.8 & & 1447 & & 532 & & 401 & & 471 & & 438 & & 738 & \\
\hline & $20-40$ & 0 & & 9 & & 9 & & 14.42 & & 3.52 & & 4.91 & & 4.11 & & 4.50 & & 1.00 & \\
\hline & $41-50$ & 12.4 & & 31.7 & & 18.5 & & 1617 & & 552 & & 323 & & 450 & & 44 & & 456 & \\
\hline & $41-30$ & 1 & & 9 & & 8 & & 10.17 & & 3.02 & & 3.25 & & 4.59 & & 4.44 & & 4.50 & \\
\hline & 5160 & 12.4 & & 24.7 & & 22.8 & & 1280 & & 237 & & 237 & & 316 & & 681 & & 368 & \\
\hline & $31-00$ & 2 & & 4 & & 9 & & 12.09 & & 2.31 & & 2.01 & & 0.10 & & 0.04 & & 3.00 & \\
\hline & $>60$ & 4.50 & & $\begin{array}{r}16.0 \\
0\end{array}$ & & 9.00 & & 7.00 & & 3.00 & & 3.00 & & 0.00 & & 1.00 & & 1.00 & \\
\hline & $<4000$ & 14.2 & 0.97 & 26.4 & & 20.2 & 0.76 & 13.93 & 1.18 & 5.51 & 0.79 & 4.59 & 1.23 & 4.51 & 0.8 & 4.83 & 1.31 & 5.74 & 1.2 \\
\hline Income & & 4 & & 1 & & 1 & & & & & & & & & 7 & & & & \\
\hline & $4000-5999$ & 14.3 & & 27.9 & & 22.7 & & 14.53 & & 4.83 & & 4.15 & & 3.82 & & 4.43 & & 7.77 & \\
\hline
\end{tabular}




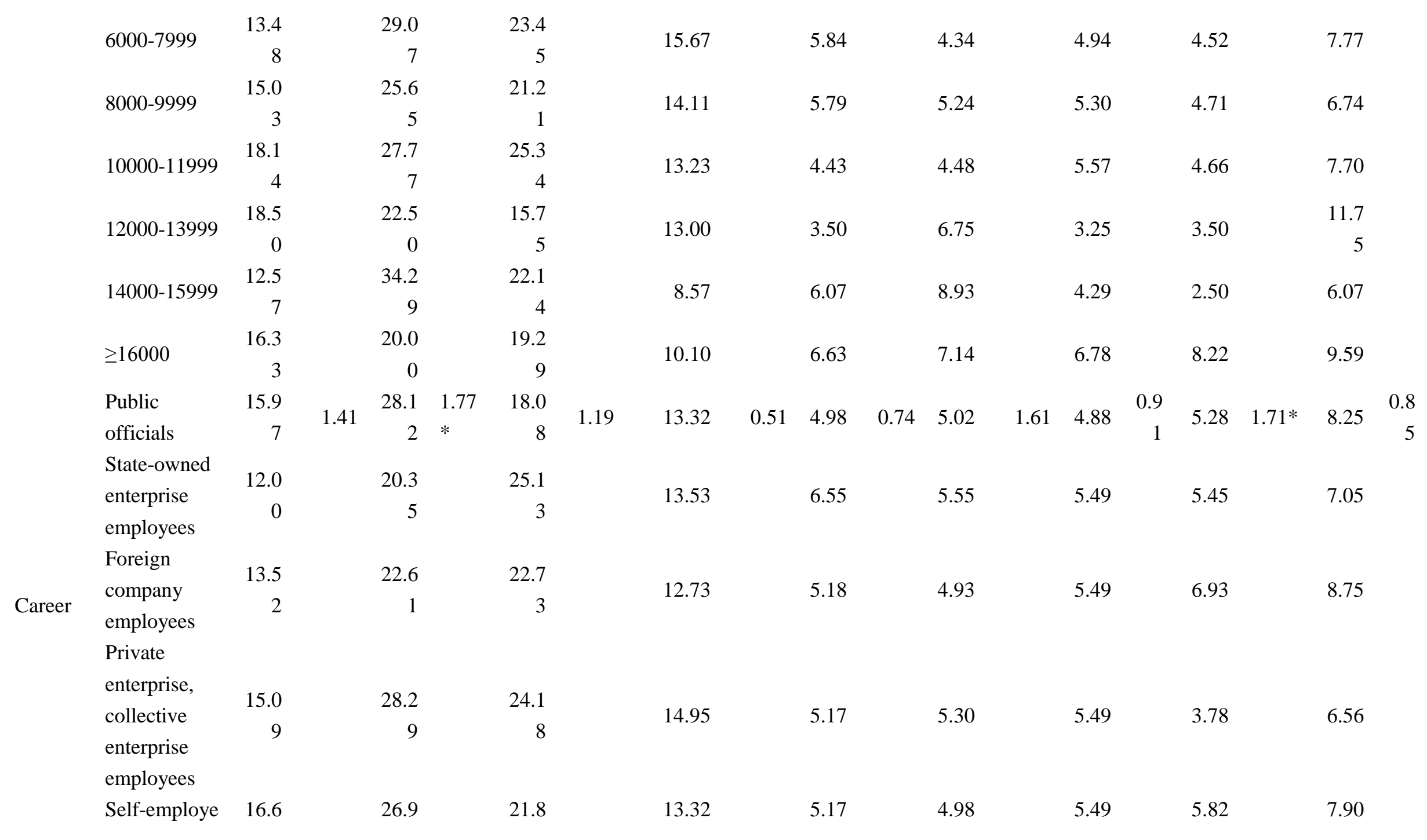




\begin{tabular}{|c|c|c|c|c|c|c|c|c|c|c|c|c|c|c|c|c|}
\hline & d persons & 3 & & 7 & 7 & & & & & & & & & & & \\
\hline & & 12.0 & & 28.8 & 16.3 & & & & & 473 & & & & & & \\
\hline & Farmers & 0 & & 4 & 8 & 10.30 & & 5.17 & & 4.13 & & 5.63 & 4.38 & & 0.10 & \\
\hline & & 10.8 & & 36.7 & 24.3 & & & & & 234 & & & & & 445 & \\
\hline & Workers & 6 & & 0 & 2 & 10.48 & & 3.11 & & 2.34 & & 3.45 & 2.59 & & 4.45 & \\
\hline & Retired and & 12.2 & & 22.7 & 21.1 & & & & & & & & & & & \\
\hline & work & 2 & & 8 & 1 & 14.44 & & 3.15 & & $1.6 /$ & & 1.94 & 1.94 & & 4.58 & \\
\hline & Studentc & 14.8 & & 25.3 & 22.0 & 1307 & & 606 & & 463 & & 434 & 579 & & $664+2$ & \\
\hline & 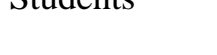 & 3 & & 2 & 2 & 10.01 & & 0.00 & & 4.05 & & 4.24 & 0.13 & & 0.04 & \\
\hline & Other creerc & 20.0 & & 34.1 & 12.5 & 1708 & & 375 & & 11.2 & & 750 & 202 & & 250 & \\
\hline & UIICT lareers & 0 & & 7 & 0 & 17.00 & & 0.15 & & 5 & & 1.00 & 2.92 & & 2.00 & \\
\hline & Elementary & & $2.65^{*}$ & 25.9 & 10.5 & & $3.93 *$ & & & & & 12.1 & & & & 1.6 \\
\hline & $\begin{array}{l}\text { school or } \\
\text { below }\end{array}$ & 8.54 & * & 6 & 8 & 7.50 & $* *$ & 7.12 & 0.42 & 4.04 & 1.10 & 2 & 4.42 & 0.09 & 5.19 & 8 \\
\hline & Junior high & 11.5 & & 31.5 & 18.6 & 1846 & & 571 & & 330 & & & & & & \\
\hline & school & 4 & & 2 & 8 & 18.40 & & 5.11 & & 3.30 & & 3.66 & 4.38 & & 7.14 & \\
\hline & High & 12.9 & & 27.1 & 24.1 & & & & & & & & & & & \\
\hline Educati & school/secon & Whe & & - & - & 13.46 & & 5.12 & & 4.23 & & 4.91 & 4.64 & & 4.81 & \\
\hline on & dary school & & & & & & & & & & & & & & & \\
\hline & College/high & 15.5 & & 28.4 & 22.5 & 1685 & & 490 & & 429 & & 512 & 456 & & 5.49 & \\
\hline & er vocational & 1 & & 3 & 0 & $10.0 J$ & & 4.90 & & 4.29 & & 3.12 & 4.50 & & 3.49 & \\
\hline & Bachelor & 16.0 & & 26.6 & 22.2 & 1345 & & 568 & & 515 & & 423 & 4.99 & & 776 & \\
\hline & Dactivior & 7 & & 8 & 2 & $10.4 \mathrm{~J}$ & & 0.00 & & (15 & & 4.23 & (1.97 & & 1.10 & \\
\hline & Master's & 12.0 & & 21.8 & 20.0 & 985 & & 523 & & 662 & & 5.62 & 4.92 & & 9.00 & \\
\hline & degree or & 0 & & 5 & 0 & 8.00 & & 5.25 & & 0.02 & & & 1.52 & & & \\
\hline
\end{tabular}




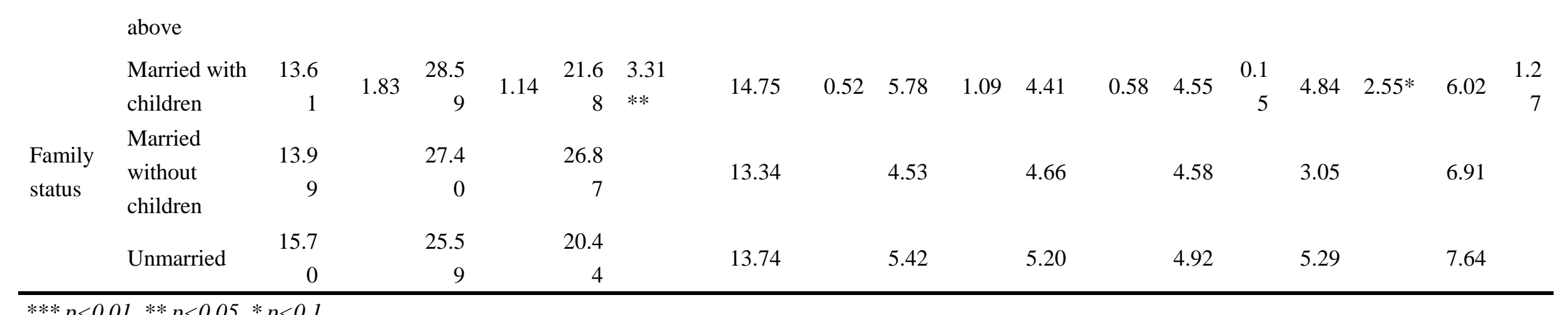

359

360 
363 The results of regression indicate that the variables of gender, age, family status,

364 education, food neophilia, most valued part of meals, satisfaction with meals, travel

365 purpose, dining place, familiarity with the Tibetan cuisine all have a significant effect

366 on FWRE (Table 6). Most importantly, variables of food neophilia and satisfaction

367 with meals exert the largest/most significant (negative) effect. Tourists prepared to

368 taste unfamiliar food are more likely to consume the ordered Tibetan food. And

369 tourists more satisfied with the food on the trip would left less food uneaten.

370

371 Table 6. Tobit model regression results of tourist food waste in Lhasa

\begin{tabular}{lrrrr}
\hline Variable symbol & Coef. & St.Err. & t-value & p-value \\
\hline gender & 2.466 & 1.159 & 2.13 & $0.034^{* *}$ \\
age & 5.772 & 3.786 & 1.52 & 0.128 \\
age_sq & -1.020 & 0.537 & -1.90 & $0.058^{*}$ \\
married_chr & -1.805 & 1.533 & -1.18 & 0.239 \\
married_nochr & -3.136 & 1.759 & -1.78 & $0.075^{*}$ \\
educaton & 6.984 & 2.847 & 2.45 & $0.014^{* *}$ \\
educaton_sq & -0.872 & 0.365 & -2.39 & $0.017 * *$ \\
public_officials & 3.347 & 3.314 & 1.01 & 0.313 \\
employees & -0.474 & 3.651 & -0.13 & 0.897 \\
employees_for & -0.911 & 3.888 & -0.23 & 0.815 \\
employees_pri & 1.754 & 3.211 & 0.55 & 0.585 \\
self-employed & 3.870 & 3.253 & 1.19 & 0.235 \\
workers & 1.162 & 3.469 & 0.34 & 0.738 \\
retired & 1.524 & 3.865 & 0.39 & 0.693 \\
students & 2.389 & 3.543 & 0.67 & 0.500 \\
career_other & 7.621 & 5.032 & 1.51 & 0.130 \\
income & 0.405 & 0.347 & 1.17 & 0.244 \\
religion & 1.698 & 1.601 & 1.06 & 0.289 \\
local & -1.870 & 2.682 & -0.70 & 0.486 \\
neophilia & -3.374 & 1.291 & -2.61 & $0.009 * * *$ \\
importance_food & 0.265 & 0.356 & 0.75 & 0.457 \\
appearence & 2.553 & 3.777 & 0.68 & 0.499 \\
volume & -3.922 & 3.118 & -1.26 & 0.209 \\
price & -2.594 & 1.910 & -1.36 & 0.175
\end{tabular}




\begin{tabular}{|c|c|c|c|c|}
\hline nutrition & -2.211 & 2.004 & -1.10 & 0.270 \\
\hline health & -2.102 & 1.271 & -1.65 & $0.099 *$ \\
\hline food_other & -0.268 & 10.158 & -0.03 & 0.979 \\
\hline proportion_local & 0.024 & 0.028 & 0.84 & 0.399 \\
\hline meal_satisfaction & -1.675 & 0.563 & -2.98 & $0.003 * * *$ \\
\hline times & 0.941 & 1.147 & 0.82 & 0.412 \\
\hline sightseeing & -0.523 & 1.243 & -0.42 & 0.674 \\
\hline leisure_vac & -2.156 & 1.096 & -1.97 & $0.050^{*}$ \\
\hline culture_act & 0.063 & 1.102 & 0.06 & 0.954 \\
\hline religious_wor & 3.203 & 2.215 & 1.45 & 0.149 \\
\hline meeting & -1.067 & 2.414 & -0.44 & 0.659 \\
\hline research & -2.319 & 3.251 & -0.71 & 0.476 \\
\hline purpose_other & -7.453 & 3.607 & -2.07 & $0.039^{* *}$ \\
\hline food_tib & -0.512 & 1.134 & -0.45 & 0.652 \\
\hline stomach & -3.052 & 2.679 & -1.14 & 0.255 \\
\hline food & -2.273 & 2.502 & -0.91 & 0.364 \\
\hline culture & 0.035 & 2.373 & 0.01 & 0.988 \\
\hline knowledge & -0.522 & 3.950 & -0.13 & 0.895 \\
\hline days & 0.013 & 0.077 & 0.17 & 0.869 \\
\hline companion_50 & 1.653 & 1.683 & 0.98 & 0.326 \\
\hline companion_18 & 2.787 & 1.818 & 1.53 & 0.126 \\
\hline number_tou & 0.101 & 0.249 & 0.40 & 0.687 \\
\hline snack & 5.828 & 2.464 & 2.37 & $0.018 * *$ \\
\hline ordinary & 4.501 & 2.377 & 1.89 & $0.059^{*}$ \\
\hline hotel & 7.679 & 3.387 & 2.27 & $0.024 * *$ \\
\hline friends & 4.525 & 3.653 & 1.24 & 0.216 \\
\hline location_other & 12.052 & 5.368 & 2.25 & $0.025^{* *}$ \\
\hline table & 1.953 & 2.445 & 0.80 & 0.425 \\
\hline order & -1.753 & 2.273 & -0.77 & 0.441 \\
\hline home_food & -0.360 & 0.370 & -0.97 & 0.331 \\
\hline tibetan_food & -0.883 & 0.362 & -2.44 & $0.015 * *$ \\
\hline not_serious & -1.314 & 1.698 & -0.77 & 0.439 \\
\hline serious & 0.095 & 1.787 & 0.05 & 0.958 \\
\hline disinterest & -2.372 & 2.208 & -1.07 & 0.283 \\
\hline gevonerment & 1.742 & 2.311 & 0.75 & 0.451 \\
\hline restarurant & 0.713 & 1.249 & 0.57 & 0.568 \\
\hline relationship_other & -9.765 & 6.374 & -1.53 & 0.126 \\
\hline Constant & 5.086 & 10.472 & 0.49 & 0.627 \\
\hline
\end{tabular}




\subsection{Food waste composition and patterns of wasteful behaviour among tourists}

375 Tourists generated circa $15 \%$ of the total food waste in the HORECA sector of Lhasa, 376 Compared to food wastage at home, they produced about 1.7 times more food waste 377 when on travel. Moreover, the food waste level is higher than the published food wastage level of Chinese rural households (2.4\%) in 2013 (F. Li, et al., 2017), household's FWRE established in China Health and Nutrition Survey (CHNS) during 1999 2009 (3.25\% 4.78\%) (Xiong \& Wang, 2017), FWRE in Chinese college canteens (12.13\%) in 2018 (Qian, Li, \& QIian, 2019) and solid waste rate (which includes food) of the Hawaian tourism industry (Saito, 2013). Past evidence reinforced with the results of this study suggests that the magnitude of food wastage in tourism is higher than the magnitude of food wastage at home, both when cooking in households and when eating out.

As for the causes of food waste, nearly half (42\%) of tourists stated they wasted food because of unsuitable taste; $28 \%$ of them indicated altitude sickness affected their appetite and $18 \%$ of them did not consume all food because they did not know the size of ordered portion size. It can therefore be concluded that taste preferences of tourists to Lhasa represent a major driver of food wastage which is in line with

392 findings reported by Beretta, Stoessel, Baier, \& Hellweg (2013) in the context of food 393 waste generation in the foodservice sector, by Blondin, Djang, Metayer,

394 Anzman-Frasca, \& Economos (2015) in schools and by Lanfranchi, Calabrò, Pascale, 395 Fazio, \& Giannetto (2016) in households. Food wastage from tourism to Lhasa is not only determined by poor familiarity of domestic tourists with the Tibetian cuisine, but also with their unawareness of a 'typical' Tibetian meal size. Portion size is a well-established driver of food wastage (Massow \& McAdams, 2015) and, as it increases, so does the amount of wasted food (Freedman \& Brochado, 2010; Ofei, Holst, Rasmussen, \& Mikkelsen, 2015). Careful portion size control is considered a 
meaningful measure to mitigate food waste occurence on consumer plates (Kallbekken \& Sælen, 2013).

There is evidence to suggest that tourists tend to consume more food on holiday than at home (Gossling, 2015), spending almost a third of their travel budget on food (Torres, 2003). The results of this study indicate that excessive food consumption by tourists may not necessarily mean that more food is consumed when on holiday, but that more food is wasted instead. Tourists like trying unfamiliar food, especially locally distinctive foodstuffs in exotic locations, which is to gain a better experience of different cultures (Scarpato, 2002). Some new, unfamiliar dishes may not always meet the taste preferences of every tourist, thus driving food wastage. In this regard, the experience economy is usually seen positively as tourists seek new, authentic experiences, thus benefiting the locals. This quest may however have a dark side to it, for example when the (food) experience is not to someone's personal taste, then this brings about excessive (food) wastage. Personal well-being is another reason for tourists wasting food in Lhasa. The average altitude of Lhasa is above 3600 meters; tourists feeling uncomfortable, may have a poor appetite meaning higher amounts of food left on their plates.

Variables of gender, age, family status, education, food neophilia, most valued part of meals, satisfaction of meals, travel purpose, dining place, familiarity with Tibetan food have a significant effect on FWRE:

Female tourists waste significantly more food. This finding is consistent with research on household food waste (Koivupuro, et al., 2012; Silvennoinen, et al., 2014) and school food waste (Buzby \& Guthrie, 2002; Kuo \& Shih, 2016; Painter, et al., 2016). Dietary pursuits by females may, at least partially, explain the difference in food wastage in comparison with males which is in line with findings reported in Filimonau, Lemmer, Marshall, \& Bejjani (2017). Concurrently, evidence shows that females are more willing to taste the unknown food (Mak, et al., 2012), thus 
suggesting that females are more likely to order food which they do not subsequently like and, therefore, waste.

The effect of age on FWRE presents an "inverted U-shaped" feature which means that, within a certain age range, the effect of age on the FWRE is positive; after reaching a certain limit age, the impact on food waste is negative. This confirms the findings of Zhang, et al. (2018) and can be explained by the fact that the middle-aged (26 40) consumers usually eat more than youngsters but the elderly consumers tend to restrict food intakes because of heath and/or financial reasons (Visschers, Wickli, \& Siegrist, 2016). Similar findings are reported for food wastage in the context of households where the explicit impact of (older) age has been recorded (Quested, Marsh, Stunell, $\&$ Parry, 2013). This study shows that the younger tourists waste a higher proportion of fruits and aquatic products. This may be attributed to health considerations in food consumption that are of particular relevance to the younger demographics (Wansink \& Johnson, 2015).

\section{The FWRE values of married tourists without children are significantly lower than} those of unmarried tourists. This finding partially supports Derqui, Fernandez, \& Fayos (2018) who highlight excessive food wastage generated by children in the context of school canteens. It can further be assumed that families are more concerned with the impact of food on health and might, therefore, order less food or order smaller meal portions. High food wastage among single consumers is confirmed by Koivupuro, et al. (2012) and can, at least partly, be explained by the desire of singletons to enjoy holiday, and the food consumed on holiday, in absence of any household obligations.

Education has a significant "inverted U-shaped" impact on FWRE of tourists. This implies the limitation of educating consumers on reducing food waste which is in line with Zhang, et al. (2018). Highly educated people have a better awareness of the impact of food waste on the environment (D. Y. Qi \& Roe, 2016). Therefore, they pay 
more attention to their food consumption behaviors and avoid wastage (Abdelradi, 2018; Mattar, Abiad, Chalak, Diab, \& Hassan, 2018; Song, Li, Semakula, \& Zhang, 2015). Secondi, et al. (2015) indicate that people who have a lower level of education also waste low amounts of food but attribute this to lower incomes of this category of consumers and higher personal values they subsequently assign to food.

Tourists willing to try unfamiliar food have a significantly lower FWRE. As one important motivation for tourism (Mak, et al., 2013), food neophilia encourages tourists to consume food representative of aspecific destination, such as Tibetan meals in Lhasa, and waste less of that food even if taste is not always 'right'. Conversely, if tourists have food neophobia, it will influence their willingness to taste the unknown food and thereby their preferences to novel foods (Tsimitri, et al., 2018; Tuorila, Lahteenmaki, Pohjalainen, \& Lotti, 2001). This study shows that, when more Tibetan specialty was ordered (by tourists and/or their companions), food waste was easily generated.

\section{Personal satisfaction with the meals served is significantly negatively correlated with} tourist FWRE. As an index of foodservice quality, food waste could reflect consumer satisfaction (Aminuddin, Vijayakumaran, \& Razak, 2018; Ferreira, Martins, \& Rocha, 2013). Satisfaction of meals is also the most intuitive embodiment of whether the food can satisfy tourist appetite and can directly determine whether the food is likely to be wasted. Higher rates of food waste are well correlated with customer dissatisfaction with meals (Carvalho, et al., 2015).

Tourists on leisure vacation demonstrate significantly lower values of FWRE. This category of tourists may assign more value to the natural scenery and activities and pay less attention to food, considering it a functional, rather than experiential, attribute of their holiday. Thus, their diet structure and consumption are closer to that in the at-home context. They are less likely to consume unknown food and, therefore, generate waste. In contrast, more food waste produced by tourists on a business and/or 
study trip can be attributed to the high frequency of food consumption occasions, but also to the social pressure element which can influence food wastage (Papargyropoulou, et al., 2016; F. Qi, Sun, Ge, \& Cui, 2014; Zeng, 2015).

Compared to dining at the restaurants that cater for tour groups, the FWRE values of tourists dining at specialty snack bars, ordinary restaurants, and star-rated hotels were higher. Fixed menus operated by many tourist restaurants are normally less wasteful than traditional, long menus adopted by many regular, a la carte, restaurants. This is assigned to limited food choice which implies less wastage generated in restaurant kitchens (Huang, He, \& Li, 2018; Papargyropoulou, et al., 2019).

Regarding the perception of food consumption, better tourist familiarity with the Tibetan food implies lower FWRE. As an important form of tourism cultural experience, tasting the specialties of a destination is a common consumption behavior of tourists (Frisvoll, et al., 2016). However, tourists" "known" or "safe" experiences could affect their food consumption. Knowing what to expect implies limited scope for (unpleasant) surprises in the form of unliken food and, consequently, waste (Fenton, Eves, Kipps, \& Odonnell, 1995).

\subsection{Mitigation strategies and actions}

Building (more) sustainable food systems by facilitating food waste reduction has become a priority for many national and international stakeholders (Derqui, et al., 2018; Mourad, 2016). This signifies the need for policy and industry designed interventions to reduce food waste occurrence in the different sectors of economic activity (S. K. Cheng, et al., 2017). Such interventions should be underpinned by systematic, empirical research (S. K. Cheng, et al., 2017). Given the larger magnitude of food wastage in the tourism context compared to the household and 'dining out' contexts, urgent food waste reduction interventions are required in China. Considering the multifaceted impacts of food waste, its reduction campaigns should involve 
multiple stakeholders, such as the national government of China, the HORECA industry association, the HORECA providers, and the customers (tourists).

A number of grassroot initiatives have been launched around the world to aid in food waste minimization within the tourism industry. Examples include the "Zero Waste tourism" campaign in Slovenia (Oblak \& Meia, 2017), the EU LIFE FOSTER Project in Malta (Maltachamber, 2019), the BUFFET (Building an Understanding For Food Excess in Tourism) campaign in Asia Pacific (Pawson, 2018) and the Food Bank project in the UAE (Stepfeed, 2017). Given the above initiatives are rather recent, their impact on consumer (tourist) behaviour is yet unknown. This notwithstanding, it is argued that all these projects can provide a useful insight into the challenge of combating food waste in the tourism industry in China, subject to their adaptation to the local food consumption context.

For the government, the major task is to streamline food quality standards in the national HORECA sector. The Chinese government has already implemented a series of policies and taken relevant measures to reduce food waste (Zhang, Bai, Liu, \& Cheng, 2019) but, whilst being useful, the above initiatives focus on food consumption occasions when people go to eat out in their leisure time and do not encapsulate the very special and large consumer group of tourists. The institutions in charge should pay more attention to the policy guidance and supervision of HORECA providers in China. This can be done by, for example, introducing relevant guidelines or by standardizing the approaches to preparing food dishes and designing menus. The special/unusual foods should be clearly marked to avoid blind ordering which may cause unnecessary food wastage in the destinations with unique cuisines that distinctly different from the more 'mainstream' cuisines of China.

Education has a significant impact on tourist FWRE within a certain range; hence, strengthening education of tourists on food consumption and nutrition represents a 
necessary means to reduce food waste in tourism. Considering the importance of education in adolescents in terms of personal growth, character formation, and values, as well as the effective impact of nutrition education on eating habits and, consequently, on food waste reduction (Kim, Choi, Lee, \& Kwak, 2007), it is necessary for the Chinese government to mobilise its education department and focus on strengthening food waste related education for young(er) people. The government should also consider supporting the non-profit companies or industry organizations to run food waste reduction campaigns in schools, colleges and universities. Successful examples can be learnt from the "Do Good: Save Food!” campaign in France (FAO, 2019; FAO \& International Food Waste Coalition, 2018) and the "Love Food Hate Waste" (www.lovefoodhatewaste.com) campaign in the UK. Also the "Gourmet Bag" project launched by the French government and the "Source Reduction" efforts shared by the United States Environmental Protection Agency (EPA) can provide useful insights into food waste reduction in restaurants (futureofwaste, 2018).

For professional/industry associations, these should standardize corporate behavior, strengthen publicity and education, and promote responsible food consumption among tourists. As social intermediaries, the national HORECA industry associations in China should publicize and implement the national food waste reduction policies and regulations, timely reflect the food waste problems and offer possible solutions to their members. They should further organize staff and management training on how to achieve food waste reduction in HORECA enterprises in popular tourists destinations in China.

Foodservice provides should combine efforts to reduce food waste in their operations, paying more attention to the optimization of kitchen processes, work with suppliers, staff training and consumer choice architecture (Filimonau \& De Coteau, 2019). As a special form of eating out, similar measures should be applied by HORECA providers to address the challenge of tourist food waste. As taste preferences drive tourist food 
waste in Lhasa, the HORECA providers should strive to improve the quality of dishes they cook to meet tourist satisfaction. Adopting menus to meet tourist preferences, developing strategies to improve meal acceptance and customer satisfaction (Carvalho, et al., 2015), and requesting feedback from clients as a regular assessment of the food waste reduction measures (for instance, conduct customer satisfaction surveys and interviews) are necessary. Portion size control should also be adopted and the HORECA operators providing tourists with a choice of meal sizes, especially when serving unfamiliar dishes. Moreover, a customer reminder service (for example, about the weight and approximate taste of the dishes) is also essential to avoid food waste caused by blind ordering for tourists who may be unfamiliar with a local cuisine.

It has been emphasized that consumer behavior represents an important challenge to HORECA food waste mitigation (Filimonau, Fidan, et al., 2019; Filimonau, Krivcova, et al., 2019; Ge, Almanza, Behnke, \& Tang, 2018; Radwan, Jones, \& Minoli, 2010). Under the national culture of China (mianzi), Chinese consumers tend to order more food than they really need (L. E. Wang, et al., 2017). In the domestic tourism context, the same situation is equally inevitable. Tourists usually leave some food on the plate due to shyness or in order to show generosity, especially when eating with non-family members. To better understand the local diet to reduce food waste, tourists should learn about local food culture in advance and proactively request the dishes' details before ordering. However, as tourists with higher-level education waste less food, it is necessary for tourists to educate themselves to acquire knowledge of the detrimental societal and environmental effects of food waste (Filimonau, Matute, et al., 2019). This study demonstrated that most domestic tourists in China believed that food waste prevention was a prime responsibility of consumers (tourists). Awareness building represents a fundamental step to let tourists to realize their importance in food waste reduction. 


\section{Conclusion}

598 Being a cornerstone of a holiday experience, food consumption in tourism represents 599 a topic of growing academic interest. However, extant scholarly research has mostly 600 considered food consumption as a 'pleasurable' element of holiday. This study has 601 shown the 'dark' side of food consumption on holidays by establishing the magnitude 602 of food wastage among tourists in Lhasa, a popular tourist destination in China, and 603 by revealing the main determinants of wasteful behaviour, including the effect of 604 various socio-demographic characteristics. We found that tourists waste more food 605 when on travel than when cooking at home and when eating out at home. The main 606 drivers include food preference, portion size, educational level, food neophilia, meal 607 satisfaction and such socio-demographic characteristics as gender, age, family status 608 and educational level.

609

610 Constrained by time and funding, this project obtained the data on tourist FWRE and 611 the FWRO of particular foodstuffs by using a self-completion questionnaire rather 612 than by the method of direct weighting of wasted food. In the survey, $10 \%$ of tourists 613 stated they did not waste food on this trip. This may signify the effect of social

614 desirability bias. However, by comparing the FWRE and the FWRO of particular food 615 in the tourism and at-home contexts for the same consumer, as well as by conducting 616 a comprehensive analysis of the main drivers of tourist food waste in a popular tourist 617 destination, we believe our research can contribute to a comparative study of 618 out-home and at-home food consumption in the tourism field and food field, and the 619 policy/measures taken for tourist food waste reduction.

621 Future research should strive to procure more accurate food waste data by tourists by 622 the method of direct weighting. The analytical framework developed in this study to 623 measure food waste generated by tourists can be replicated in other tourism contexts. 624 Future research can also aim at adopting a mixed method approach to investigation, 
i.e. by, supplementing the quantitative element of research (a consumer survey) with the qualitative element (in-depth tourist interviews) to better understand the drivers of wasteful tourist behaviour. Exploring food wastage by international tourists to China and by comparing it with food wastage by domestic tourists represents another promising research opportunity. Lastly, interviews with local HORECA providers and Chinese policy-makers on how tourist behaviour can be modified to make it less wasteful should also be conducted.

\section{Declaration of competing interest}

The authors declare no competing conflict of interest.

\section{References}

Abdelradi, F. (2018). Food waste behaviour at the household level: A conceptual framework. Waste Management, 71, 485-493.

Aminuddin, N. F., Vijayakumaran, R. K., \& Razak, S. A. (2018). Patient satisfaction with hospital foodservice and its impact on plate waste in public hospitals in East Malaysia. Hospital Practices and Research, 3, 90-97.

Aschemann-Witzel, J., de Hooge, I., Amani, P., Bech-Larsen, T., \& Oostindjer, M. (2015). Consumer-related food waste: causes and potential for action. Sustainability, 7, 6457-6477.

Beretta, C., Stoessel, F., Baier, U., \& Hellweg, S. (2013). Quantifying food losses and the potential for reduction in Switzerland. Waste Management, 33, 764-773.

Blondin, S. A., Djang, H. C., Metayer, N., Anzman-Frasca, S., \& Economos, C. D. (2015). 'It's just so much waste.' A qualitative investigation of food waste in a universal free School Breakfast Program. Public Health Nutrition, 18, 1565-1577.

Bone, P. F. (1995). Word-of-mouth effects on short-term and long-term product judgments. Journal of Business Research, 32, 213-223.

Buzby, J. C., \& Guthrie, J. F. (2002). Plate Waste in School Nutrition Programs. Final Report to Congress. USDA, Washington, DC.

Carvalho, J. G., Lima, J. P. M., \& Rocha, A. M. C. N. d. (2015). Food waste and consumer satisfaction with the food service of Hotel and Tourism School of Coimbra, Portugal. Demetra: food, nutrition \& health, 10, 405-418.

Cheng, S. K., Bai, J. F., Jin, Z. H., Wang, D. Y., Liu, G., Gao, S., Bao, J. L., Li, X. T., Li, R., Jiang, N. Q., J., Y. W., \& Zhang, S. G. (2017). Reducing food loss and food waste: some personal 
reflections. Journal of Natural Resources, 32, 529-538.

Cheng, S. K., Jin, Z. H., Liu, G., Liu, X. J., \& Yu, X. (2018). Horeca Food Waste Report in Chinese Cities. WWF, Beijing.

Chung, S. S. (2008). Using plastic bag waste to assess the reliability of self-reported waste disposal data. Waste Management, 28, 2574-2584.

Davenport, E. C., Davison, M. L., Liou, P. Y., \& Love, Q. U. (2015). Reliability, dimensionality, and internal consistency as defined by cronbach: distinct albeit related concepts. Educational Measurement-Issues and Practice, 34, 4-9.

Derqui, B., Fernandez, V., \& Fayos, T. (2018). Towards more sustainable food systems. Addressing food waste at school canteens. Appetite, 129, 1-11.

Dobson, J. (2015). Achieving food equity: Access to good local food for all. Journal of Urban Regeneration \& Renewal, 8, 122-132.

Elimelech, E., Ert, E., \& Ayalon, O. (2019). Bridging the gap between self-assessments and measured household food waste: A hybrid valuation approach. Waste Management, 95, 259-270.

Falasconi, L., Cicatiello, C., Franco, S., Segre, A., Setti, M., \& Vittuari, M. (2019). Such a shame! A study on self-perception of household food waste. Sustainability, 11.

FAO. (2013). Food Wastage Footprint: Impacts on Natural Resources. Summary Report. FAO, Rome.

FAO. (2019). Awareness raising in schools to prevent food waste. http://www.fao.org/save-food/projects/educationalmaterial-fwr/en/. (Accessed May 21 2019).

FAO, IFAD, UNICEF, WFP, \& WHO. (2018). The state of food security and nutrition in the world 2018: Building climate resilience for food security and nutrition. FAO, Rome.

FAO, \& International Food Waste Coalition. (2018). Do Good: Save Food! Education material package on food waste reduction in primary and secondary schools. For age group 4 (fourteen years up), Rome, Italy.

Fenton, J., Eves, A., Kipps, M., \& Odonnell, C. C. (1995). The nutritional implications of food wastage in continuing care wards for elderly patients with mental-health problems. Journal of Human Nutrition and Dietetics, 8, 239-248.

Ferreira, M., Martins, M. L., \& Rocha, A. (2013). Food waste as an index of foodservice quality. British Food Journal, 115, 1628-1637.

Filimonau, V., \& De Coteau, D. A. (2019). Food waste management in hospitality operations: A critical review. Tourism Management, 71, 234-245.

Filimonau, V., Dickinson, J., Robbins, D., \& Reddy, M. V. (2013). The role of 'indirect' greenhouse gas emissions in tourism: Assessing the hidden carbon impacts from a holiday package tour. Transportation Research Part a-Policy and Practice, 54, 78-91.

Filimonau, V., Fidan, H., Alexieva, I., Dragoev, S., \& Marinova, D. D. (2019). Restaurant food waste and the determinants of its effective management in Bulgaria: An exploratory case study of restaurants in Plovdiv. Tourism Management Perspectives, 32.

Filimonau, V., Krivcova, M., \& Pettit, F. (2019). An exploratory study of managerial approaches to food waste mitigation in coffee shops. International Journal of Hospitality Management, 76, 48-57.

Filimonau, V., Lemmer, C., Marshall, D., \& Bejjani, G. (2017). 'Nudging' as an architect of more responsible consumer choice in food service provision: The role of restaurant menu design. Journal of Cleaner Production, 144, 161-170.

Filimonau, V., Matute, J., Kubal-Czerwińska, M., \& Krzesiwo, K., Mika, M. (2019). The determinants 
of consumer engagement in restaurant food waste mitigation in Poland: an exploratory study. In: Journal of Cleaner Production.

Freedman, M. R., \& Brochado, C. (2010). Reducing portion size reduces food intake and plate waste. Obesity, 18, 1864-1866.

Frisvoll, S., Forbord, M., \& Blekesaune, A. (2016). An empirical investigation of tourists' consumption of local food in rural tourism. Scandinavian Journal of Hospitality and Tourism, 16, 76-93.

futureofwaste. (2018). How to prevent food waste in tourism and events? . https://futureofwaste.makesense.org/food-waste/. (Accessed May 26 2019).

Ge, L., Almanza, B., Behnke, C., \& Tang, C. H. (2018). Will reduced portion size compromise restaurant customer's value perception? International Journal of Hospitality Management, 70, 130-138.

Getlinger, M. J., Laughlin, C. V. T., Bell, E., Akre, C., \& Arjmandi, B. H. (1996). Food waste is reduced when elementary-school children have recess before lunch. Journal of the American Dietetic Association, 96, 906-908.

Ghinea, C., \& Ghiuta, O. A. (2019). Household food waste generation: young consumers behaviour, habits and attitudes. International Journal of Environmental Science and Technology, 16, 2185-2200.

Gossling, S. (2015). New performance indicators for water management in tourism. Tourism Management, 46, 233-244.

Huang, H. F., He, Y., \& Li, D. (2018). Pricing and inventory decisions in the food supply chain with production disruption and controllable deterioration. Journal of Cleaner Production, 180, 280-296.

Juvan, E., Grun, B., \& Dolnicar, S. (2018). Biting off more than they can chew: food waste at hotel breakfast buffets. Journal of Travel Research, 57, 232-242.

Kallbekken, S., \& Sælen, H. (2013). 'Nudging' hotel guests to reduce food waste as a win-win environmental measure. Economics Letters, 119, 325-327.

Kasavan, S., Mohamed, A. F., \& Halim, S. A. (2019). Drivers of food waste generation: Case study of island-based hotels in Langkawi, Malaysia. Waste Management, 91, 72-79.

Kim, S. H., Choi, E. H., Lee, K. E., \& Kwak, T. K. (2007). Effects of nutrition education on food waste reduction. J Korean Diet Assoc, 13, 357-367.

Koivupuro, H. K., Hartikainen, H., Silvennoinen, K., Katajajuuri, J. M., Heikintalo, N., Reinikainen, A., \& Jalkanen, L. (2012). Influence of socio-demographical, behavioural and attitudinal factors on the amount of avoidable food waste generated in Finnish households. International Journal of Consumer Studies, 36, 183-191.

Kormos, C., \& Gifford, R. (2014). The validity of self-report measures of proenvironmental behavior: A meta-analytic review. Journal of Environmental Psychology, 40, 359-371.

Kuo, C. F., \& Shih, Y. H. (2016). Gender differences in the effects of education and coercion on reducing buffet plate waste. Journal of Foodservice Business Research, 19, 223-235.

Lanfranchi, M., Calabrò, G., Pascale, A. D., Fazio, A., \& Giannetto, C. (2016). Household food waste and eating behavior: empirical survey. British Food Journal, 118, 3059-3072.

Li, F., Jiang, W. B., Zhu, Y. Y., \& Qian, Z. (2017). Food waste and its causes in rural China-based on an accounting survey of 25 provinces (municipalities) in China. Grain Science and Technology and Economy, 42, 24-28. 
Li, Y. Y., Filimonau, V., Wang, L. E., \& Cheng, S. K. (2020). Tourist food consumption and its arable land requirements in a popular tourist destination. Resources Conservation and Recycling, 153.

Li, Y. Y., Wang, L. E., \& Cheng, S. K. (2019). Tourists' food consumption characteristics and influencing factors in tourism cities on the plateau: an empirical study of Lhasa. Resources Science, 41, 494-508.

Mak, A. H. N., Lumbers, M., Eves, A., \& Chang, R. C. Y. (2012). Factors influencing tourist food consumption. International Journal of Hospitality Management, 31, 928-936.

Mak, A. H. N., Lumbers, M., Eves, A., \& Chang, R. C. Y. (2013). An application of the repertory grid method and generalised Procrustes analysis to investigate the motivational factors of tourist food consumption. International Journal of Hospitality Management, 35, 327-338.

Maltachamber. (2019). Tackling food waste in Malta's tourism industry. https://www.maltachamber.org.mt/en/tackling-food-waste-in-malta-s-tourism-industry. (Accessed May 25 2019).

Massow, M. v., \& McAdams, B. (2015). Table scraps: An evaluation of plate waste in restaurants. Journal of Foodservice Business Research, 18, 437-453.

Mattar, L., Abiad, M. G., Chalak, A., Diab, M., \& Hassan, H. (2018). Attitudes and behaviors shaping household food waste generation: Lessons from Lebanon. Journal of Cleaner Production, 198, 1219-1223.

Mourad, M. (2016). Recycling, recovering and preventing "food waste": competing solutions for food systems sustainability in the United States and France. Journal of Cleaner Production, 126, 461-477.

National Bureau of Statistics. (2020). Resident income and consumption expenditure in 2019. http://www.stats.gov.cn/tjsj/zxfb/202001/t20200117_1723396.html. (Accessed 2-20 2020).

National Bureau of Statistics of China. (2019). China Statistical Yearbook. Beijing: China Statistics Press.

Oblak, E., \& Meia, E. B. (2017). More tourists equals more waste. https://zerowasteeurope.eu/2017/03/more-tourists-equals-more-waste/. (Accessed May 18 2019).

Ofei, K. T., Holst, M., Rasmussen, H. H., \& Mikkelsen, B. E. (2015). Effect of meal portion size choice on plate waste generation among patients with different nutritional status. An investigation using Dietary Intake Monitoring System (DIMS). Appetite, 91, 157-164.

Painter, K., Thondhlana, G., \& Kua, H. W. (2016). Food waste generation and potential interventions at Rhodes University, South Africa. Waste Management, 56, 491-497.

Papargyropoulou, E., Lozano, R., Steinberger, J. K., Wright, N., \& bin Ujang, Z. (2014). The food waste hierarchy as a framework for the management of food surplus and food waste. Journal of Cleaner Production, 76, 106-115.

Papargyropoulou, E., Steinberger, J. K., Wright, N., Lozano, R., Padfield, R., \& Ujang, Z. (2019). Patterns and causes of food waste in the hospitality and food service sector: food waste prevention insights from Malaysia. Sustainability, 11.

Papargyropoulou, E., Wright, N., Lozano, R., Steinberger, J., Padfield, R., \& Ujang, Z. (2016). Conceptual framework for the study of food waste generation and prevention in the hospitality sector. Waste Management, 49, 326-336.

Parfitt, J., Barthel, M., \& Macnaughton, S. (2010). Food waste within food supply chains: 
quantification and potential for change to 2050. Philosophical Transactions of the Royal Society B-Biological Sciences, 365, 3065-3081.

Parizeau, K., von Massow, M., \& Martin, R. (2015). Household-level dynamics of food waste production and related beliefs, attitudes, and behaviours in Guelph, Ontario. Waste Management, 35, 207-217.

Pawson, H. (2018). Pacific Asia Travel Association launches BUFFET tourism food waste campaign. https://www.moodiedavittreport.com/pacific-asia-travel-association-launches-buffet-tourism-f ood-waste-campaign/. (Accessed May 28 2019).

Pettinger, C., Holdsworth, A., \& Gerber, A. (2004). Psycho-social influences on food choice in Southern France and Central England. Appetite, 42, 307-316.

Population Census Office under the State Council of China, \& National Bureau of Statistics of China. (2012). Tabulation on the 2010 Population Census of People's Republic of China. Beijing: China Statistics Press.

Qi, D. Y., \& Roe, B. E. (2016). Household food waste: multivariate regression and principal components analyses of awareness and attitudes among U.S. consumers. PloS One, 11, e0159250.

Qi, F., Sun, B. L., Ge, S. A., \& Cui, S. P. (2014). Stop food waste without delay. Social Perspective, 12, 185-189.

Qian, L., Li, F., \& QIian, Z. (2019). Factors affecting food waste in college canteens. Resources Science, 41, 1859-1870.

Quested, T. E., Marsh, E., Stunell, D., \& Parry, A. D. (2013). Spaghetti soup: The complex world of food waste behaviours. Resources Conservation and Recycling, 79, 43-51.

Radwan, H. R. I., Jones, E., \& Minoli, D. (2010). Managing solid waste in small hotels. Journal of Sustainable Tourism, 18, 175-190.

ReFED. (2016). A Roadmap to Reduce US Food Waste by 20 Percent. ReFED.

Saito, O. (2013). Resource use and waste generation by the tourism industry on the big island of Hawaii. Journal of Industrial Ecology, 17, 578-589.

Scarpato, R. (2002). Gastronomy as a tourist Product: The perspective of gastronomy studies. In A. M. Hjalager \& G. Richards (Eds.), Tourism and gastronomy (pp. 51-70). London: Routledge.

Secondi, L., Principato, L., \& Laureti, T. (2015). Household food waste behaviour in EU-27 countries: A multilevel analysis. Food Policy, 56, 25-40.

Sekaran, U. (2003). Research methods for business, a skill building approach. New Delhi: Ar Emm International.

Silvennoinen, K., Katajajuuri, J. M., Hartikainen, H., Heikkila, L., \& Reinikainen, A. (2014). Food waste volume and composition in Finnish households. British Food Journal, 116, 1058-1068.

Song, G. B., Li, M. J., Semakula, H. M., \& Zhang, S. S. (2015). Food consumption and waste and the embedded carbon, water and ecological footprints of households in China. Science of the Total Environment, 529, 191-197.

Stancu, V., Haugaard, P., \& Lahteenmaki, L. (2016). Determinants of consumer food waste behaviour: Two routes to food waste. Appetite, 96, 7-17.

Stepfeed. (2017). Copies of Quran 'shoved in toilet' in Germany after being ripped apart. https://stepfeed.com/dubai-wants-to-be-the-1st-city-in-the-middle-east-with-zero-food-waste-7 076. (Accessed May 28 2019).

Suki, N. M., \& Suki, N. M. (2015). Does religion influence consumers' green food consumption? Some 
insights from Malaysia. Journal of Consumer Marketing, 32, 584-585.

Thyberg, K. L., \& Tonjes, D. J. (2016). Drivers of food waste and their implications for sustainable policy development. Resources Conservation and Recycling, 106, 110-123.

Torres, R. (2003). Linkages between tourism and agriculture in Mexico. Annals of Tourism Research, 30, 546-566.

Tsimitri, P., Michailidis, A., Loizou, E., Mantzouridou, F. T., Gkatzionis, K., \& Mugampoza, E. (2018). Bioeconomy and the production of novel food products from agro-industrial wastes and residues under the context of food neophobia. AgBioForum, 21, 97-106.

Tuorila, H., Lahteenmaki, L., Pohjalainen, L., \& Lotti, L. (2001). Food neophobia among the Finns and related responses to familiar and unfamiliar foods. Food Quality and Preference, 12, 29-37.

van der Werf, P., Seabrook, J. A., \& Gilliland, J. A. (2020). Food for thought: Comparing self-reported versus curbside measurements of household food wasting behavior and the predictive capacity of behavioral determinants. Waste Management, 101, 18-27.

Visschers, V. H. M., Wickli, N., \& Siegrist, M. (2016). Sorting out food waste behaviour: A survey on the motivators and barriers of self-reported amounts of food waste in households. Journal of Environmental Psychology, 45, 66-78.

Vitasari, P., Wahab, M. N. A., Herawan, T., Othman, A., \& Sinnadurai, S. K. (2011). Re-test of State Trait Anxiety Inventory (STAI) among Engineering Students in Malaysia: Reliability and Validity tests. Procedia Social and Behavioral Sciences, 15, 3843-3848.

Wang, L. E., Liu, G., Liu, X. J., Liu, Y., Gao, J., Zhou, B., Gao, S., \& Cheng, S. K. (2017). The weight of unfinished plate: A survey based characterization of restaurant food waste in Chinese cities. Waste Management, 66, 3-12.

Wang, L. E., Xue, L., Li, Y. Y., Liu, X. J., Cheng, S. K., \& Liu, G. (2018). Horeca food waste and its ecological footprint in Lhasa, Tibet, China. Resources, Conservation \& Recycling, 136, 1-8.

Wang, Z. C., \& Li, J. L. (2006). Study on the tour industry spatial layout of the Yangtze River Delta. ECONOMIC Geography, 26, 83-86.

Wansink, B., \& Johnson, K. (2015). Adults only: why don't children belong to the clean-plate club? International Journal of Obesity, 39, 375.

Wu, K. Y., Raab, C., Chang, W., \& Krishen, A. (2016). Understanding Chinese tourists' food consumption in the United States. Journal of Business Research, 69, 4706-4713.

Xiong, J., \& Wang, D. Y. (2017). Residents' food consumption characteristics and influencing factors-based on food consumption investigation in 20 provinces of China. Food and Nutrition in China, 23, 49-53.

Yoon, S.-J., \& Kim, H.-A. (2012). Elementary school students' perception of food waste and factors affecting plate waste rate of school foodservice in the Gyeongnam area. Journal of the Korean Dietetic Association, 18, 126-140.

Zeng, M. (2015). How to create a consumption environment where food is not wasted. Social Perspective, 33, 214-215.

Zhang, P. P., Bai, J. F., Liu, X. J., \& Cheng, S. K. (2019). Food waste at the consumer segment: Impact and action. Journal of Natural Resources, 34, 437-450.

Zhang, P. P., Wang, L. E., Bai, J. F., Liu, X. J., Cheng, S. K., \& Fu, S. P. (2018). The food waste behavior of catering consumers from a tourism perspective. Resources Science, 40, 1186-1195.

Zorpas, A. A., \& Lasaridi, K. (2013). Measuring waste prevention. Waste Management, 33, 1047-1056. 
${ }^{*}$ Declaration of Interest Statement

The authors declare no competing conflict of interest. 
Wang Ling-en: Investigation, Conceptualization, Methodology, WritingReviewing and Editing, Project administration

Viachaslau Filimonau: Data curation, Visualization, Writing- Reviewing and Editing

Li Yunyun: Investigation, Software, Writing- Original draft preparation, Formal analysis 

Supplementary File
Click here to download Supplementary File: Questionnaire on Food Consumption of Tourists in Lhasa.docx

Supplementary File
Click here to download Supplementary File: Questionnaire on Food Consumption of Tourists in Lhasa.docx to

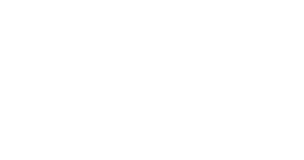

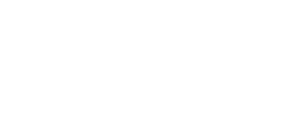

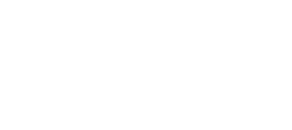

